\title{
Did Long-Memory of Liquidity Signal the European Sovereign Debt Crisis?
}

\author{
Sun $^{\mathrm{a}}$, Z., P. A. Hamill ${ }^{\mathrm{b}}$, Y. Lic ${ }^{*}$, Y. C. Yang ${ }^{\mathrm{d}}$, and S. A. Vigne \\ ${ }^{a}$ Financial Conduct Authority, 25 The North Colonnade, Canary Wharf, London, E14 5HS. \\ ${ }^{b}$ Emirates Institute for Banking and Financial Studies, PO Box 341400, Dubai, UAE. \\ 'Queen's Management School, Queen's University Belfast, BT9 5EE, UK. \\ ${ }^{\mathrm{d} U n i v e r s i t y ~ C o l l e g e ~ D u b l i n, ~ L o c h l a n n ~ Q u i n n ~ S c h o o l ~ o f ~ B u s i n e s s, ~ B e l f i e l d, ~ D u b l i n ~ 4, ~ I r e l a n d ~}$
}

This paper analyses high frequency MTS data to comprehensively evaluate the liquidity of the European sovereign bond markets before and during the European sovereign debt crisis for eleven countries. The Hill index, Generalized Hurst exponent and Dynamic Conditional Score (DCS) are employed to evaluate the properties of the bid-ask spread. Sovereign bonds exhibit the stylized facts reported for a range of financial markets. The 1-minute interval analysis indicates the level of bid-ask spread exhibits long-memory and the change in bid-ask spread experiences volatility clustering. Long-memory effects diminish (disappear) for 5-minute (15minute) interval, and for short-term maturity (peripheral countries) is stronger than long-term maturity (core countries). Analysis of sub-periods indicates that longmemory process reached its peak during European sovereign debt crisis from May 2010 to December 2011. This analysis suggests that estimating long-memory parameters for high-frequency data could be a useful tool to monitor market stability.

Keywords: European Sovereign Debt; Liquidity; Long-memory

JEL Classification: C1, G01, G11

*Corresponding author. Email: y.li@qub.ac.uk

Acknowledgement: Youwei Li acknowledges the support of National Natural Science

Foundation of China (no. 71571197). 


\section{Did Long-Memory of Liquidity Signal the European Sovereign Debt Crisis?}

This paper analyses high frequency MTS data to comprehensively evaluate the liquidity of the European sovereign bond markets before and during the European sovereign debt crisis for eleven countries. The Hill index, Generalized Hurst exponent and Dynamic Conditional Score (DCS) are employed to evaluate the properties of the bid-ask spread. Sovereign bonds exhibit the stylized facts reported for a range of financial markets. The 1-minute interval analysis indicates the level of bid-ask spread exhibits long-memory and the change in bid-ask spread experiences volatility clustering. Long-memory effects diminish (disappear) for 5minute (15-minute) interval, and for short-term maturity (peripheral countries) is stronger than long-term maturity (core countries). Analysis of sub-periods indicates that long-memory process reached its peak during European sovereign debt crisis from May 2010 to December 2011. This analysis suggests that estimating long-memory parameters for high-frequency data could be a useful tool to monitor market stability.

Keywords: European; Sovereign Debt; Liquidity; Long-memory

JEL Classification: C1, G01, G11 


\section{Introduction}

This paper investigates the distributional properties and long-memory of the bid-ask spread for high-frequency data from the Mercato dei Titoli di Stato (MTS) inter-dealer fixed-income securities platform for European sovereign bond markets from July 2005 to December 2011. ${ }^{1}$ The prevalent bid-ask spread reflects the fundamental costs of immediate trading and the underlying liquidity for a particular asset which is an important metric in the market microstructure literature (Wilinski, Cui, Brabazon and Hamill, 2015). It is of central importance to market participants for a range of reasons. Liquidity affects asset pricing and expected returns and is particularly important for high-frequency trading, which has become a major influence on financial markets, with high-frequency traders being extremely sensitive to trading costs (Amhiud and Mendelson, 1986; Amihud, 2002; O’Hara, 2014, Bowen, Hutchinson and O'Sullivan, 2010). From a policy perspective regulatory authorities seek to maintain financial stability and manage "peak-load" problems caused by flights into, and out of, markets during periods of financial crises and stress (Beber, Brandt and Kavajecz, 2008). And as banks are important investors in sovereign bond markets this raises the issue of the "bank-sovereign nexus" relationship and the potential for this channel to affect financial stability (Lane, 2012; Buch, Loetter and Ohls, 2016; Honohan, 2016; ESRB, 2015).

The European Central Bank's Long-Term Refinancing Operations (LTRO) and Outright Monetary Transaction (OMT) policy interventions highlight the importance of maintaining European bond market liquidity. These initiatives injected liquidity into sovereign bond markets and Mario Draghi's famous “whatever it takes” speech in London on the $26^{\text {th }}$ July 2012 sought to restore investor confidence. Failure to restore bonds market stability didn't appear to be an option given the potential macroeconomic consequences. One estimate suggests a sovereign liquidity shock could generate a 7\% drop in output and investment as well as a $2 \%$ increase in unemployment (Gutkowski, 2017). The aim of this paper is to evaluate the liquidity of a range of European sovereign bond markets across maturities and varying high-frequency intervals for long-memory to investigate if parameter estimates provided a signal of market instability.

This paper investigates the European sovereign bond inter-dealer market from 1 July 2005 until 31 December 2011 using high frequency data from MTS at 1- , 5-, and 15-minute intervals for eleven European countries including: Austria, Belgium, Germany Spain, Finland, France, France, Ireland Italy, Netherlands and Portugal for 3-, 6-, and 10-year maturities. In the context of the current literature this represents a comprehensive analysis of European debt markets $^{2}$. We apply a range of methodologies. After our initial exploratory data analysis, we draw upon Extreme Value Theory (EVT) to examine the relative extremes of each country's distribution. Next, we apply Matteo's (2007) Generalized Hurst exponent approach to evaluate the time-scale dependence of the statistical properties of the bid-ask spread, and use Andres and Harvey’s (2012) Dynamic Location/Scale model to test for long-memory.

Our analysis indicates that bid-ask spread distributional properties of each market is consistent with the stylized facts for financial time-series data including fat-tails, volatility

\footnotetext{
${ }^{1}$ MTS data is the European equivalent of GovPX data in the U.S.

${ }^{2}$ A significant barrier to analyzing high-frequency financial data is access to software which has the capacity to manage large datasets. We thank Kx Systems, Palo Alto, and their European partner, First Derivatives, for providing their $\mathrm{KDB}+$ database management software which was used in this paper to manage the bond market data.
} 
clustering and long-memory in volatility. There is also evidence of multi-scaling behaviour for long-memory. At the 1-minute interval over the full sample period the bid-ask spread for all markets exhibits long-memory and experience volatility clustering which is stronger for shortterm maturity than for long-term maturity, and is stronger for the peripheral countries of Ireland, Greece and Portugal than for core countries. The long-memory features start to appear from the beginning of the Global Financial Crisis and reaches its peak during European Sovereign Debt Crisis which persists and intensifies to the end of the Sovereign Debt Crisis up to December 2011. Data frequency appears to be important. The long-memory effect of the bidask spread declines significantly at the 5-minute interval and the long-memory effect fluctuates a lot for some countries, such as Italy and Austria. In the 15-minute interval estimation longrange dependence disappears. Overall, this paper finds that long-memory has the potential to be a useful monitoring tool of market stability, as evidence by the European sovereign debt crisis, and that regulators and market participants should pay attention to data frequency and maturity when monitoring these markets. The applicability of this approach to other markets is an avenue with scope for further research.

The rest of the paper is organized as follows: section 2 reviews the literature; section 3 outline and justifies the methodologies employed; section 4 reports the empirical results, while section 5 provides summarising our key findings.

\section{Literature Review}

Theoretical models suggest that the adverse selection component of the bid-ask spread reflects information asymmetry among market participants and that that the bid-ask spread is the dominant factor influencing decisions between different order types on equity markets. Traders can either be patient and submit limit orders or pay the bid-ask spread premium to submit market orders for immediate execution (Copeland and Galai, 1983; Kyle, 1985; Glosten and Milgrom, 1985; Easley and O'Hara, 1992; Foucault, 1999; Foucault, Kadan and Kandel, 2005). Limit-orders and market-orders submission strategies have also been shown to be dependent upon quoted bid-ask spreads (Biais, Hillion and Spatt, 1995; Harris and Hasbrouck, 1996; Ranaldo, 2004; Hall and Hautsch, 2006; Pascual and Veredas, 2009). Liquidity has also been shown to be the dominant determinant of volatility in equity markets for short time scales and that long-memory of liquidity rather than volume is a key factor influencing volatility on the NYSE, London and Shenzen stock markets (Farmer, Patelli and Zovko, 2005; Lillo and Farmer, 2004; Farmer, Patelli and Zovko, 2005; Vasiliki, Gopikrishnan and Stanley, 2005; Weber and Rosenow, 2006; Gillemot, Farmer and Lillo, 2006; Gu, Chen and Zhou, 2007; La spade, Farmer and Lillo, 2008; Mike and Farmer, 2008). A number of studies have focused on the ability of long-memory methodologies to test, and predict, bubbles and crashes for individual stocks and the S\&P 500 at high frequency (Frömmel and Kruse, 2012; Barany et al., 2012; Shahiduzzaman-Quoreshi, 2014). These papers support the contention that long-memory methodologies can be used to monitor market stability with parameter estimates approaching 0.5 (no memory) in the run up to a crash and revert to long memory immediately after the crash. Also, this type of behaviour was most evident for 1-minute interval data. The majority of literature investigating long-memory of the bid-ask spread concentrates on equity markets.

For European sovereign bond markets two papers investigate the inter-relationship between credit quality and liquidity over two periods focusing on episodes of stress which also highlights the idiosyncratic features of the European sovereign bond markets in contrast to the 
extensive literature for US corporate and sovereign bond markets. Beber, Brandt and Kavajecz (2009) motivate their analysis by the idiosyncratic feature of the European government bond market which exhibits a strong, and unique, negative correlation between credit quality and liquidity, which contrasts with the positive correlation reported for the U.S. debt market. This negative correlation allows Beber et al. (2009) to empirically disentangle flights-to-quality and flights-to-liquidity ${ }^{3}$. They analyse MTS data from April 2003 to December 2004. Their stress events over this period include the invasion of Iraq, the Madrid bombings, Saudi Arabia bombings and a Tsunami. They show that the bulk of sovereign yield spreads is explained by differences in credit quality, but during periods of stress investors value liquidity supporting a flight-to-liquidity as opposed to quality. More recently, Pelizzon, Subrahmanyam, Tomio and Uno (2016) investigate the relation between credit risk and liquidity for the Italian sovereign bond market during the Eurozone crisis and the impact of subsequent European Central Bank (ECB) interventions. They report that credit risk influences the liquidity of the market with this relationship exhibiting a threshold effect, becoming stronger, when the CDS spread exceeds 500 basis points (bp). And that ECB Long-Term Refinancing Operations (LTRO) interventions lead to a structural break which significantly diminished the intensity of credit-risk liquidity relationship from the onset of 2012. Pelizzon et al. (2016) point out that there is a dearth of empirical evidence for European sovereign bond markets with a handful of papers tending to examine limited time periods mostly prior to the global financial crisis which focus on the impact of market liquidity on bond yields (Coluzzi, Ginebri and Turco 2008, Dufour and Ngugen, 2012; Favero, Pagano and von Thadden, 2010; Bai, Julliard and Yuan, 2012).

\section{Data and Methodology}

\subsection{Data}

We investigate liquidity in the European sovereign bond interdealer market using high frequency data from MTS. MTS was set up in 1988 to improve the secondary market liquidity for Italian sovereign bonds. In 1994 MTS was reformed as an electronic trading platform in order to improve market depth and trading volume. In the late 1990's it granted entry to additional European countries whose sovereign debt instruments would be traded on separate domestic platforms. In 1999 EuroMTS was launched for specific trading of benchmark government bonds. In 2001 the MTS and EuroMTS were merged into MTS Global market. Since then MTS Global Market bond trading platform is the largest interdealer trading platform for European sovereign bonds. ${ }^{4}$ The market operates as a limit-order book which has the benefit of providing visible liquidity and enhanced price discovery with market participants able to view the full order book and signed trades as they occur.

Architecturally the MTS platform has two different market segments for trading: EuroMTS and local MTS (Domestic) Markets. The local MTS markets list the whole yield curve of the sovereign bond market of the respective European country. The range of securities being traded on the local MTS platform is however much larger than on the EuroMTS trading

\footnotetext{
${ }^{3}$ Given our focus on European sovereign debt markets we refer interested readers to the US literature to maintain the clarity and focus of our analysis: Chakravarty and Sarkar (1999), Fleming (2003), Fleming and Remolona (1999), Fleming and Mizrach (2009), Engle et al. (2012), Pasquariello and Vega (2007), Pasquariello, Roush and Vega (2012), Goyenko and Subrahmanyam and Ukhov (2011).

${ }^{4}$ There exist other trading platforms, such as ICAP, EUREX, EBS and D2002.
} 
platform. EuroMTS is the reference electronic market for Euro benchmark sovereign bonds which have an outstanding value of at least $€ 5$ billion. Fixed income securities can be traded on both of the local and EuroMTS platforms. ${ }^{5}$ The participants of both platforms can either be a dealer or a market maker (usually primary dealer). ${ }^{6}$ Market makers have the obligation to provide firm two-way quotes under specific restrictions for each asset class, while dealers do not have the obligation. Also, for some asset classes, it is possible to have more than one market maker. Both platforms operate as independent limit order books in our sample period; and they have the same trading hours following central European time (CET). On each day, it begins with a pre-market phase (7:30-8:00), a pre-open phase (Opening auction period: 8:00-8:15) and open phase (Continuous trading period 8:15 - 17:30). During the continuous trading period, the order matching mechanism follows price-time priority.

In this study, the bid-ask spread is defined as the absolute differences between the best ask price and the best bid price. We analyze the best bid-ask spread of 3-Year, 6-Year and 10-Year Austrian, Belgium, Finish, French, German, Greek, Irish, Italian, Netherland, Portuguese and Spanish government bonds being traded on the Local MTS platforms from 1 July 2005 until 31 December 2011. Since several significant events took place during our study period, in addition, we divided the full sample into four sub-periods:

- Pre-Crisis Period (PRE): $1^{\text {st }}$ July 2005 to $14^{\text {th }}$ July 2007.

- Global Financial Crisis (GFC): $15^{\text {th }}$ July 2007 to $15^{\text {th }}$ January 2009: from July 2007 banks in the UK stopped lending to each other due to market fears that counterparts were exposed to the emerging US sub-prime crisis. In July Bear Sterns informed investors that they would get little, if any, money back from two hedge funds with large holdings of sub-prime mortgages. LIBOR rates spike. Following a BBC report on the $13^{\text {th }}$ September, Northern Rock experienced a bank-run on the $14^{\text {th }}$. It was subsequently nationalised on $22^{\text {nd }}$ February 2008.

- European Sovereign Debt Crisis (EDC1): $16^{\text {th }}$ January 2009 to $7^{\text {th }}$ May 2010: On $15^{\text {th }}$ January 2009, the Irish government announced that it would nationalise Anglo Irish Bank. Fall 2009 Greece's budget was revised highlighting that the deficit for that year would be significantly higher than previously predicted. On $2^{\text {nd }}$ May 2010 the EU endorsed the IMF announce an €85bn first European financial rescue plan for Greece.

- European Sovereign Debt Crisis (EDC2): $8^{\text {th }}$ May 2010 to $31^{\text {st }}$ December 2011: Problems persisted and Greece and a second rescue package was negotiated with Greece in 2011. On 28 ${ }^{\text {th }}$ November 2010 the Trokia (European Commission, European Central Bank and International Monetary Fund agreed an €85bn bailout deal with the Irish Government. On $5^{\text {th }}$ May 2011 Portugal agrees with the EU and IMF on a €78bn bailout in exchange for an austerity programme. Pelizzon et al. (2016) show that for Italian sovereign bonds it wasn't until the start of 2012 that ECB interventions (the Long-Term Refinancing Operations: LTRO) diminished the impact of credit risk which suggests it wasn't until this point that the crisis period ended economically. Splitting the European sovereign debt crisis period into two periods allows us to evaluate each period individually and against each other.

\footnotetext{
${ }^{5}$ This depends on particular requirements, i.e. the principal amount outstanding and the available number of dealers and may acquire the Euro "benchmark" status.

${ }^{6}$ This is an exclusive interdealer market composed of large capitalized banks; individual investors cannot access this market.
} 


\subsection{Methodology}

After our initial exploratory data analysis, the Hill tail-index is estimated to model the relative extremes of the Probability Density Functions (PDFs) of the bid-ask spreads. Beirlant et al. (2004) has a detailed account of Extreme Value Theory (EVT) and Hill index. Next, we examine the time-scale dependence of the statistical properties of the bid-ask spread. Multiscaling processes are widely applied to test for long-memory of financial data which can be characterized by its Hurst index $H$ which ranges from 0 to 1 with values categorised as:

- $H$ ranges from 0 to 0.5

- $H \approx 0.5$

- $H$ ranges from 0.5 to 1

Between 0.5 and 1 indicates long-memory, with values close to 1 reflecting a higher degree of persistence, or long-range dependence. Between 0 and 0.5 indicates anti-persistence which exhibits strong negative correlation and a process which fluctuates violently. Values $\approx 0.5$ indicates uncorrelated series such as random walk. There are several techniques in the literature used to estimate the Hurst index. Hurst et al. (1965) introduced the re-scaled range statistical analysis R/S with the estimator Hurst exponent. However, this approach can display long-run correlations in random process. Lo (1991), Teverovsky et al. (1999), Weron and Przybylowsciz (2000) and Weron (2002) argued that this approach lacked robustness since it was very sensitive to the presence of short-memory, heteroskedasticity, outliers, and multiple scale behaviour. Lo (1991) modified the R/S analysis which added some weights and covariance estimators to the standard deviation and a truncation lag $(q)$ to its denominator. The truncation $q$ is an important choice variable. The value of $q$ must not be too small as the autocorrelation beyond lag $q$ may be substantial and should be included in the weighted sum. In this study, we adopt Matteo (2007) Generalized Hurst exponent approach since it combines the sensitivity to any type of dependence in the data to a computationally straight forward and simple algorithm. This method examines the scaling properties of the data directly via the computation of the $q$-order moments of the distribution of the increments. The $q$-order moments are much less sensitive to the outliers than the maxima/minima and different exponents' $q$ are associated with different characterizations of the multi-scaling complexity of the signal (Matteo, 2007). This method allows us to distinguish between uni-scaling and multiscaling process. In the case of uni-scaling process, the scaling behaviour is determined by the unique constant $H$ that is consistent with the Hurst exponent where $q H(q)$ is linear $(H(q)=H)$. In the case of multi-scaling process, $H(q)$ depends on $q$ where $q H(q)$ is non-linear ${ }^{7}$.

Finally, we employ the Harvey (2013) Dynamic Conditional Score (DCS) model to investigate the time-varying nature of long-memory and fat-tail effects in the bid-ask spreads. Alizadeh, Brandt and Diebold (2002) stochastic volatility model and Engle and Lee (1999) two-component model examine the volatility with a long-run and a short-run component. The main role of the short-run component is to pick up the temporary increase in volatility after a large shock. These models can reveal long memory behaviour. However, Alizadeh, Brandt and

\footnotetext{
${ }^{7}$ There are other methods to estimate the Hurst index: detrended fluctuation analysis (Ausloos, 2000), wavelet transform module maxima (WTMM) method (Percival and Walden, 2000), multi-affine analysis (Peng et al., 1994), periodogram regression (Geweke and Porter-Hudak, 1983), the moving-average analysis technique (Ellinger, 2000), multi-fractal/multiaffine analysis (Ivanova and Ausloos, 1999). In the empirical finance literature, Liu et al. (1997) and Liu et al. (1999); Vasiliki, Gopikrishnan and Stanley (2005) and Gu, Chen and Zhou (2007) applied detrended fluctuation analysis (DFA) to investigate the long-range correlation of bid-ask spread in various developed and emerging equity markets. However, most of them suffer from sensitivity and lack of robustness as discussed above.
} 
Diebold (2002) argue the interpretability of the two component model "stands in sharp contrast to that of long memory fractionally integrated volatility, which often appears mysterious and nonintuitive”. The DCS two-component volatility model is easier to handle than the twocomponent GARCH model on the non-negative variables. There will be after-shocks for a few periods after a very large movement. A one-component GARCH model reacts too much, with the increased conditional variance taking a long time to come down. Andres and Harvey (2012) and Harvey (2013) argue that the specification of $\sigma^{2}$ as a linear combination of past squared observations in GARCH is taken for granted, but the consequences are that it corresponds too much to extreme observations and the effect is slow to disappear. The DCS model can be written as: Given observations $y_{t}, y_{t}=\varepsilon_{t} \exp \left(\lambda_{t \mid t-1}\right), \mathrm{t}=1, \ldots, \mathrm{T}, 0<\varepsilon_{t}<\infty$, and $\lambda_{t}=\omega+\lambda_{t}^{l}+\lambda_{t}^{s}$ with $\lambda_{t}^{l}=\varphi_{1} \lambda_{t-1}^{l}+\theta_{1} u_{t-1}$ and $\lambda_{t}^{s}=\varphi_{2} \lambda_{t-1}^{s}+\theta_{2} u_{t-1}$. The innovation term $u_{t-1}$ depends on the distributional specification; it is proportional to the first derivative of the log-density with respect to $\lambda_{t \mid t-1}$. See Andres (2014) for details.

Therefore, the DCS model for non-negative data is applied to investigate the bid-ask spread under assumptions of the generalized gamma or generalized beta distributions. The innovation is the score of the conditional distribution in DCS model. The statistical theory of DCS models for non-negative variables is simplified by the fact that for gamma and Weibull distributions the score and its derivatives are dependent on a gamma variate whereas for the Burr, log-logistic and $F$ distributions the dependence is on a beta variate. In fact, the theory can be rationalized by regarding the gamma and Weibull distributions as special cases of the generalized gamma distributions, whereas the Burr and log-logistic distributions as special cases of the generalized beta distributions. The generalized beta distributions are particularly useful in situations where there is evidence of heavy tails. These methodologies outlined above to investigate the fat-tail and long-memory effect are extensive and well established in Harvey (2013).

\section{Empirical Results}

\subsection{Descriptive Statistics}

Table 1 reports the monthly trading volumes for selected benchmark sovereign bonds on both of the local MTS and the EuroMTS platforms abbreviated to MTS and EBM respectively. The benchmark sovereign bonds being traded on the local platforms are significantly higher than those on the EuroMTS trading platforms in terms of the average number of trades, average dollar volume and average trading volume across countries and maturity without exception. In terms of the range of values, Panel A reports that Austrian EBM (MTS) at 6-year maturity had an average of 4.914 (33.458) trades per-month whereas at the other extreme Italian EBM (MTS) had an average of 62.431 (1201.986) for 10-year maturity.

\section{INSERT TABLES 1 \& 2 ABOUT HERE}


This is a post-peer-review, pre-copyedit version of an article published in Annals of Operations Research. The final authenticated version is available online at: $h$ ttps://doi.org/10.1007/s10479-0182850-y

Table 2 reports summary statistics for the bid-ask spread over the entire sample period and subperiods for Local MTS (MTS) ${ }^{8}$. Peripheral countries are referred to as GIIPS (Greece, Ireland, Italy Portugal and Spain) in the literature, with the remaining countries in our study referred to core countries. The mean of the bid-ask spread in peripheral countries such as Greece, Ireland and Portugal is significantly larger than those of the core countries. For instance, in the 10Ysovereign bonds, the mean bid-ask spread of the three countries ranges from 3.1608 to 3.8253 while other core countries only range from 0.0873 to 0.3713 . The mean bid-ask spread of each country increases with the maturities. The $10 \mathrm{Y}$-sovereign bonds have the widest bid-ask spread while the 3Y-maturities have the narrowest. Next, we split the full sample periods into four sub-periods. Panel B gives detailed sub-period estimates. The results reveal that the mean bidask spread increases from the pre-crisis period to (PRE) to the second sovereign crisis period (EDC2) with the GIIPS (Greece, Ireland, Italy, Portugal and Spain) experiencing significant increases in bid-ask spreads from the first to the second sovereign debt crisis sub-sample. For example, Greece increased from 3.1606 in EDC1 to 9.5950 in EDC2 for 3-year maturing. Ireland went from 0.8211 to 7.692 over the same sub-periods. Portugal had a similar experience to Ireland. The spreads increase with maturity across the countries. Ireland's spreads increased from 1.402 in EDC1 to 8.9724 for EDC2 for 6-year maturity. For 10-year maturity equivalent spreads were 1.8642 and 9.7904. Portugal and Greece experienced similar absolute increases to Ireland, whereas Italy and Spain's increases were significant but much less in absolute terms. For 10-year maturity Spain (Italy) increased from 0.3315 (0.2273) to $0.5992(0.3966)$.

\subsection{Extreme Values Analysis}

When estimating tail indices the key decision variable is the tail cut-off point ${ }^{9}$. This choice involves a trade-off between bias and variance. If the cut-off point is chosen conservatively with few order statistics in the tail, then the tail estimate will be sensitive to outliers in the distribution and have a high variance. On the other hand, if the tail includes observations in the central part of the distribution, the variance is reduced but the estimate is biased upward. In this study, since the samples are very large, we choose three cut-off points: $0.5 \%, 1.0 \%$ and $1.5 \%$ of the total observations. Results for the Hill tail-index estimates are reported in Table 3.

\section{INSERT TABLE 3 ABOUT HERE}

We only display the right tail Hill index estimation results because we are concerned with the relatively extreme bid-ask spreads. For each maturity the Hill tail-index estimates are provided on the first, second and third rows respectively for cut-off points ranging from $0.5 \%$ to $1.5 \%$ of the total observations. For example, a cut-off point of $0.5 \%$ estimates the tail-index for the largest $0.5 \%$ positive observations (it reflects the extreme large bid-ask spreads). A tail-index of zero is equivalent to the tail density of the normal distribution. The results reveal the values of the Hill tail estimates are significantly different from zero which indicates that the distribution of the bid-ask spreads of all countries on the three maturities have fat-tails. For

\footnotetext{
${ }^{8}$ The average bid-ask spread on the local MTS is slightly smaller than the EuroMTS. Our finding is consistent with Cheung, de Jong and Rindi (2005). Caporale and Girardi (2013) find the local trading platforms play a dominant role in price discovery. Therefore, we only show the results for the local platforms in the following sections as they're qualitatively similar, lead to the same overall conclusions and in the interest of parsimony.

${ }^{9}$ Extreme Value Theory (EVT) statistically deals with the behaviour of the relative extremes, or 'tails', of PDFs. Intuitively, fat-tails simply reflect the empirical fact that we observe more frequently extreme observations than would be predicted by the normal distribution, see Beirlant et al. (2004) for more details.
} 
instance, the Hill estimator for 10 -year maturity at $0.5 \%$ cut-off point ranges from 0.018 for Austria to 0.787 for Ireland. When we look at the tail-index estimates for different maturities with cut-off points $0.5 \%, 1.0 \%$ and $1.5 \%$, we find that the bid-ask spread of 10 -year maturity has less density than 6-year and 3-year in their right-tail, which, in practical terms, highlights they experienced relatively fewer extreme observations. When we examine the corresponding right-tail estimates of the bid-ask spread on different countries, it shows that Greece, Ireland and Portugal have significantly larger density than other countries which reveals they experienced relatively more extreme observations.

\subsection{Generalised Hurst Exponent and Dynamic Conditional Score (DCS)}

This section reports the results for the scaling exponents $\mathrm{H}(q)$ computed for $q=1$ and $q=2$, for $3 \mathrm{Y}-, 6 \mathrm{Y}$ - and $10 \mathrm{Y}$ sovereign bond across the full sample periods and each sub-period. When $q$ $=1, H(1)$ describes the scaling behaviour of the absolute values of the increments which is associated with the scaling of the absolute bid-ask spread in the increments. When $q=2, \mathrm{H}(2)$ measures the scaling of the autocorrelation function and is related to the power spectrum which examine the change in the bid-ask spread.

\section{INSERT FIGURE 1 AND TABLES 4 \& 5 ABOUT HERE}

Figure 1 shows the curves of $q \mathrm{H}(q)$ as a function of $q$ are not linear in $q$, but significantly bending below the linear trend. This reveals the bid-ask spread of $3 \mathrm{Y}$-sovereign bond on both EBM and MTS exhibits evidence of multi-scaling behaviour which is a sign of deviation from the Brownian, fractional Brownian, Levy and fractional Levy models. The same behaviour holds for both the case of the 6Y- and 10Y-maturities. Table 4 shows the results of the full sample period with a 1-minute interval, while Table 5 reports the estimation of two-component DCS model as specified in Section 3 of Andres (2014). Dynamic Conditional Score (DCS) models provide a convenient, relatively simple and a unified framework for modelling volatility clustering, fat-tails and long-memory in volatility. In order to choose the suitable model, the distribution have to be made. As shown in Section 4.2, the Hill tail-index estimations show that the distributions of the bid-ask spreads have heavier tails than log-normal. Therefore, the log-logistic distributions are applied in this study. Recall that $\lambda_{t}^{l}=\varphi_{1} \lambda_{t-1}^{l}+\theta_{1} u_{t-1}$ captures the long-run fluctuations of the volatility of the bid-ask spread and $\lambda_{t}^{s}=\varphi_{2} \lambda_{t-1}^{s}+\theta_{2} u_{t-1}$ represents short-run dynamics. When $\varphi_{1}$ is larger than $\varphi_{2}$, it indicates long-memory in volatility of the bid-ask spread. We find that the estimated value of $\varphi_{1}$ is statistically significantly larger than the value of $\varphi_{2}$ in most European sovereign bond markets across the three maturities. For 3-year maturity bonds, we find evidence of long memory in volatility of bid-ask spread except for Belgium, Spain, and Finland. For 6-year maturity bonds, we find evidence of long memory in volatility of bid-ask spread except for Austria, Belgium, and Italy. For 10-year maturity bonds, we find evidence of long memory in volatility of bid-ask spread except for Belgium, Spain, France, and Netherlands. Recall that in a static setting, we find $\mathrm{H}(2)<0.5$ in Table 4 which indicates there's no long memory in the volatility of the bid-ask spread. However, in a dynamic setting, the DCS estimates provides evidence of long memory in the volatility of bidask spread in most European sovereign bond markets across the three maturities. This finding for the entire sample period is consistent with the results reported in the empirical finance literature for a range of financial markets. Next we turn our attention to the sub-periods with results reported in Tables 6(a) and 6(b). 


\section{INSERT TABLE 4 AND 6(a) \& 6(b) ABOUT HERE}

Table 4 reports that the values of the generalized Hurst exponent $\mathrm{H}(1)$ are systematically greater than 0.5 whereas all the values of $\mathrm{H}(2)<0.5$. This indicates the level of bid-ask spread on European sovereign bond market possesses long-range dependence while the change of bidask spread experiences volatility clustering. In terms of maturity, the long-memory effect of the bid-ask spread on 3Y-maturaity is strongest ranging from 0.584 for the Netherlands to 0.723 for Portugal and Ireland, while the long memory effect of 10-year maturity is weaker ranging from 0.530 for the Netherlands to 0.642 for Portugal. At country level Greece, Ireland and Portugal display the greatest long-range dependence whereas Finland, Germany and the Netherland exhibit weaker long-memory. Table 6(a) reports the sub-periods Hurst index estimation results for the 1-minute interval whereas Table 6(b) reports the average Hurst index across each country over each sub-period reported in table 6(a). For 3-year maturity $\mathrm{H}(1)$ increase over each sub-period for the majority of countries. For example Germany's H(1) for the PRE, GFC, EDC1 and EDC2 was 0.348, 0.562, 0.611 and 0.693 respectively. The exceptions to this pattern where values decreased from one period to the next was for Greece from GFC (0.747) to EDC1 (0.711) which decreased again in EDC2 (0.630). Ireland decreased from EDC1 (0.745) to EDC2 (0.729), with Portugal being the only other country to experience a decrease from EDC1 (0.766) to EDC2 (0.703). From table 6(b) we can see that for the 3year maturity that, on average, across each country $\mathrm{H}(1)$ increased. The average $\mathrm{H}(1)$ was 0.388 in the PRE sub-period which increased to 0.541 for GFC, to 0.644 for EDC1 and to 0.680 for EDC2. It is evident from table 6(b) that the long-memory effect is strongest for the shorter 3year maturity. The average Hurst index for EDC1 and EDC2 are less for the 6-year maturity at 0.625 and 0.644 , respectively. For the 10-year maturity the Hurst index decreases again to 0.595 and 0.576 for EDC1 and EDC2. Given the benchmark value of 0.5 indicating a random walk, it is evident that long memory is a stronger feature of the shorter maturity bonds. This suggests that for 3-years maturity the Hurst index indicates that European sovereign debt crisis peaked in sub-period EDC2. Notable exceptions to this overall outcome include Greece's with a Hurst index of 0.747 for the GFC sub-period which decreased over the next two sub-periods. For the 10-year maturity Greece's Hurst index went from 0.644 for the GFC to 0.433 for subperiod EDC2. In addition, the generalized Hurst exponent estimations of the 5-minute and 15minute interval are reported in the Appendix as robustness tests. In the 5-minute interval analysis we find the long-memory effect is significantly reduced; and for some countries such as Italy and Austria, experience fluctuation. In the 15-minute interval estimation long-range dependence disappears for all countries across all maturities.

Ex-post, we know that within our sample of countries there was varying degrees of financial distress, with some countries being relatively stable like the Netherlands and France, whereas Ireland and Greece experienced significant instability in their sovereign bond markets and their real economies. Table 6(b) suggest that while the Hurst Index increased over the sub-periods and peaked in the last sub-period EDC2, 6(b) implies there could be value in tracking stable countries as benchmarks for those experiencing financial instability. France went from having a $\mathrm{H}(1)$ value of 0.543 for the GFC sub-period and 0.571 for the EDC1, while Ireland went from 0.506 during the GFC to 0.745 for EDC1. A sharp increase in one country's Hurst index compared to that of a stable country could imply emergence of financial instability. In absolute terms a Hurst Index $>0.7$ appears to be an indicator of financial instability. The only countries to have a $\mathrm{H}(1)>0.7$ were Greece over sub-periods GFC and EDC1, Ireland over sub-periods EDC1 and EDC2 and Portugal over the same sub-periods. 


\section{Conclusion}

This paper investigates the liquidity of the European sovereign bond interdealer market using high-frequency MTS data from $1^{\text {st }}$ July 2005 to $31^{\text {st }}$ December 2011 . We partition the crisis period into three sub-periods to investigate the initial global financial crisis from July 2007 and the subsequent European sovereign debt crisis into January 2009 to May 2010, and from May 2010 to December 2011 to capture the initial bailouts for Ireland, Greece and Portugal, and the second bailout package for Greece. Analysing eleven countries over a 5-year period for three bond maturities at three high-frequency data intervals provides a comprehensive analysis of European sovereign bond markets, and, in the context of the literature, financial markets in general. We find that European sovereign bonds exhibit the stylized facts. The 1-minute interval analysis finds that the level of bid-ask spread exhibits long-memory and the change in bid-ask spread experiences volatility clustering. Long-memory effects diminish (disappear) for 5-minute (15-minute) interval, and for short-term maturity (peripheral countries) is stronger than long-term maturity (core countries). Analysis of sub-periods indicates that long-memory process reached its peak during European sovereign debt crisis from May 2010 to December 2011.

Our findings are consistent with a body of literature examining the ability of longmemory parameters to model market crashes from high-frequency data (Frömmel and Kruse, 2012; Barany et al., 2012; Shahiduzzaman-Quoreshi, 2014). Specifically for European sovereign debt markets our analysis shows an increase in the long-memory parameter for 1minute interval data as the intensity of the debt crisis intensifies over the two sovereign debt crisis sub-periods up to December 2011. At the 5-minute interval these effects diminish and disappear at the 15-minute interval. Our analysis suggests that an absolute value of the Hurst Index greater than 0.7 is indicative of financial crisis. This implies that as a time-series methodology modelling the evolution of long-memory parameters could be a useful technique for regulators and market participants including fixed income money managers who have an interest in monitoring the stability of sovereign debt markets and trading. For European sovereign bond markets this paper provides guidance on the appropriate frequency of the data, the maturity of the bonds to analyse and suitable techniques. 


\section{References}

Alizadeh, S., Brandt, M.W. \& Diebold, F.X. (2002). Range-based Estimation of stochastic volatility models. Journal of Finance, 57, 1047-1092.

Amihud, Y. \& Mendelson, H. (1986). Asset pricing and the bid-ask spread. Journal of Financial Economics, 17(2), 223-249.

Amihud, Y. (2002). Illiquidity and stock returns: Cross-Section and time series effects. Journal of Financial Markets, 5, 31-56.

Andres, P. (2014). Maximum likelihood estimates for positive valued dynamic score models; The DySco package. Computational Statistics \& Data Analysis, Elsevier, vol. 76(C), 34-42.

Andres, P. \& Harvey, A. (2012). The dynamic location/scale model. Cambridge working Papers in Economics, CWPE 1240.

Ausloos, M. (2000). Statistical physics in foreign exchange currency and stock markets. Physica A: Statistical Mechanics and its Applications, 285(1), 48-65.

Bai, J., Julliard, C. \& Yuan, K. (2012). Eurozone Sovereign Bond Crisis: Liquidity or Fundamental Contagion. SSRN paper.

Barany, E., Beccar-Varela, M. P., Florescu, I., \& Sengupta, I. (2012). Detecting market crashes by analysing long-memory effects using high-frequency data. Quantitative Finance, 12(4), 623-634.

Beber, A., Brandt, M.W. \& Kavajecz, K.A. (2009). Flight-to-quality or flight-to-liquidity? Evidence from the euro-area bond market. Review of Financial Studies, 22(3), 925-957.

Beetsma, R., Giuliodori, M., De Jong, F. \& Widijanto, D. (2016). Price effects of sovereign debt auctions in the Euro-zone: the role of the crisis. Journal of Financial Intermediation, 25, 30-53.

Beetsma, R., Giuliodori, M., De Jong, F. \& Widijanto, D. (2013). Spread the news: The impact of news on the European sovereign bond markets during the crisis. Journal of International Money and Finance, 34, 83-101.

Beirlant, J., Goegebeur, Y., Segers, J., Teugels, J. (2004). Statistics of extremes: theory and applications. John Wiley \& Sons Inc.

Biais, B., Hillion, P. \& Spatt, C. (1995). An empirical analysis of the limit order book and the order flow in the Paris Bourse. Journal of Finance, 50(5), 1655-1689.

Buch, C., Koetter, M. \& Ohls, J. (2016). Banks and sovereign risk: A granular view. Journal of Financial Stability, 25(c), 1-15.

Bowen, D., Hutchinson, M.C. \& O’Sullivan, N. (2010). High Frequency Equity Pairs Trading: Transaction Costs, Speed of Execution and Patterns in Returns. Journal of Trading, 5(3), 31-38. 
This is a post-peer-review, pre-copyedit version of an article published in Annals of Operations Research. The final authenticated version is available online at: $h$ ttps://doi.org/10.1007/s10479-0182850-y

Caporale, G.M. \& Girardi, A. (2013). Price discovery and trade fragmentation in a multimarket environment: Evidence from the MTS system. Journal of Banking \& Finance, 37(2), 227-240.

Chakravarty, S., \& Sarkar, A. (1999). Liquidity in US fixed income markets: a comparison of the bid-ask spread in corporate, government, and municipal bond markets. Staff report no. 73 Federall Reserve Bank of New York, NY.

Cheung, Y.C., Rindi, B. \& De Jong, F. (2005). Trading European sovereign bonds: the microstructure of the MTS trading platforms. ECB Working Paper, No. 432.

Copeland, T.E. \& Galai, D. (1983). Information Effects on the Bid-Ask Spread. Journal of Finance, 38(5), 1457-1469.

Coluzzi, C., Ginebri, S. \& Turco, M. (2008). Measuring and analysing the liquidity of the Italian Treasury security wholesale secondary market. SSRN paper.

Matteo, T. (2007). Multi-scaling in finance. Quantitative Finance, 7(1), 21-36.

Dufour, A. \& Nguyen, M. (2012). Permanent trading impacts and bond yields. The European Journal of Finance, 18(9), 841-864.

Dunne, P.G., Moore, M.J. \& Portes, R. (2007). Benchmark Status in Fixed-Income Asset Markets. Journal of Business Finance \& Accounting, 34(9-10), 1615-1634.

Easley, D. \& O'hara, M. (1992). Adverse selection and large trade volume: The implications for market efficiency. Journal of Financial and Quantitative Analysis, 27(2), 185-208.

Ellinger, A. (2000). The art of investment. Wiley.

Engle, R., Fleming, M. J., Ghysels, E., Nguyen, G. (2012). Liquidity and volatility in the US treasury market: evidence from a new class of dynamic order book models, Staff Report 590, Federal Reserve Bank of New York, NY.

European Systemic Risk Board, (2015). ESRB Report on the regulatory Treatment of Sovereign Exposures. Frankfurt am Main, Available at:

http://www.esrb.europa.eu/pub/pdf/other/esrbreportregulatorytreatmentsovereignexposures03 2015.en.pdf?c0cad80cf39a74e20d9d5947c7390df1

Favero, C., Pagano, M. \& von Thadden, E. (2010). How does liquidity affect government bond yields? Journal of Financial and Quantitative Analysis, 45(1), 107-134.

Farmer, J.D., Patelli, P. \& Zovko, I.I. (2005). The predictive power of zero intelligence in financial markets. Proceedings of the National Academy of Sciences of the United States of America, 102(6), 2254-2259.

Fleming, M. J. (2003). Measuring Treasury market liquidity. Economic Policy Review, 9 (3), 83-108. 
This is a post-peer-review, pre-copyedit version of an article published in Annals of Operations Research. The final authenticated version is available online at: $h$ ttps://doi.org/10.1007/s10479-0182850-y

Fleming, M. J., Mizrach, B., 2009. The microstructure of a US Treasury ECN: the BrokerTec platform. Staff Report, Federal Reserve Bank of New York, NY.

Foucault, T. (1999). Order flow composition and trading costs in a dynamic limit order market. Journal of Financial Markets, 2(2), 99-134.

Foucault, T., Kadan, O. \& Kandel, E. (2005). Limit order book as a market for liquidity. Review of Financial Studies, 18(4), 1171-1217.

Frömmel, M. \& Robinson, K. (2012). Testing for a rational bubble under long-memory. Quantitative Finance, 12(11), 1723-1732.

Geweke, J. \& Porter-Hudak, S. (1983). The estimation and application of long memory time series models. Journal of Time Series Analysis, 4(4), 221-238.

Gillemot, L., Farmer, J.D. \& Lillo, F. (2006). There's more to volatility than volume. Quantitative Finance, 6(5), 371-384.

Girardi, A. \& Impenna, C. (2013). Price discovery in the Italian sovereign bonds market: the role of order flow. Bank of Italy Temi di Discussione (Working Paper) No, 906.

Glosten, L.R. \& Milgrom, P.R. (1985). Bid, ask and transaction prices in a specialist market with heterogeneously informed traders. Journal of Financial Economics, 14(1), 71-100.

Gopikrishnan, P., Plerou, V., Liu, Y., Amaral, L.N., Gabaix, X. \& Stanley, H.E. (2000). Scaling and correlation in financial time series. Physica A: Statistical Mechanics and its Applications, 287(3), 362-373.

Goyenko, R., Subrahmanyam, A. Ukhov, A. (2011). The term structure of bond market liquidity and its implications for expected bond returns. Journal of Financial and Quantitative Analysis, 46 (01), 111-139.

Gu, G., Chen, W. \& Zhou, W. (2007). Quantifying bid-ask spreads in the Chinese stock market using limit-order book data. The European Physical Journal B, 57(1), 81-87.

Gutkowski, V. (2017). Sovereign Illiquidity and Recessions. Available at SSRN: https://ssrn.com/abstract=2956138 or http://dx.doi.org/10.2139/ssrn.2956138.

Hall, A.D. \& Hautsch, N. (2006). Order aggressiveness and order book dynamics. Empirical Economics, 30(4), 973-1005.

Harris, L. \& Hasbrouck, J. (1996). Market vs. limit orders: the SuperDOT evidence on order submission strategy. Journal of Financial and Quantitative analysis, 31(2), 213-231.

Harvey, A. (2013). Dynamic models for volatility and heavy tails. Cambridge University Press.

Honohan, P. (2016). Debt and austerity: Post-crisis lessons from Ireland. Journal of Financial Stability, 24 (June), 149-157. 
This is a post-peer-review, pre-copyedit version of an article published in Annals of Operations Research. The final authenticated version is available online at: $h$ ttps://doi.org/10.1007/s10479-0182850-y

Huang, R.D. \& Stoll, H.R. (1997). The components of the bid-ask spread: A general approach. Review of Financial Studies, 10(4), 995-1034.

Hurst, H.E. (1951). Long-term storage capacity of reservoirs. Trans.Amer.Soc.Civil Eng., 116,770-808.

Ivanova, K. \& Ausloos, M. (1999). Low q-moment multifractal analysis of Gold price, Dow Jones Industrial average and BGL-USD exchange rate. The European Physical Journal BCondensed Matter and Complex Systems, 8(4), 665-669.

Kyle, A.S. (1985). Continuous auctions and insider trading. Econometrica, 53(6), 1315-1335.

Lane, P. R. (2012). The European Sovereign Debt Crisis. Journal of Economic Perspectives, 26(3), 49-68.

La Spada, G., Farmer, J.D. \& Lillo, F. (2008). The non- walk of stock prices: the long-term correlation between signs and sizes. The European Physical Journal B, 64(3-4), 607-614.

Lillo, F. \& Farmer, J.D. (2008). The long memory of the efficient market. Studies in Nonlinear Dynamics \& Econometrics, 8(3), 1-33.

Liu, Y., Cizeau, P., Meyer, M., Peng, C. \& Stanley, H.E. (1997). Correlations in economic time series. Physica A: Statistical Mechanics and its Applications, 245(3), 437-440.

Liu, Y., Gopikrishnan, P. \& Stanley, H.E. (1999). Statistical properties of the volatility of price fluctuations. Physical Review E, 60(2), 1390.

Matteo, T. DI (2007). Multi-scaling in finance. Quantitative Finance, 7(1), 21-36.

Menkveld, A. J., Cheung, Y.C. \& De Jong, F. (2004). Euro area sovereign yield dynamics: the role of order imbalance. ECB Working Paper, No. 385.

Mike, S. \& Farmer, J.D., 2008. An empirical behavioral model of liquidity and volatility. Journal of Economic Dynamics and Control, 32(1), 200-234.

O’Hara, M. (1995). Market microstructure theory. Blackwell Cambridge, MA.

O’Hara, M. (2014). High-frequency trading and its impact on markets. Financial Analysts Journal, 70(3), 18-27.

Overby, L.J. (2010). Liquidity and information in interdealer market: A study of hot-potato trading in the European bond market. SSRN Working Paper Series.

Pagan, A. (1996). The econometrics of financial markets. Journal of Empirical Finance, 3, 15-102.

Paiardini, P. (2010). The price impact of economic news, private information and trading intensity. Birkbeck Working Paper series, 1745-8587. 
This is a post-peer-review, pre-copyedit version of an article published in Annals of Operations Research. The final authenticated version is available online at: $h$ ttps://doi.org/10.1007/s10479-0182850-y

Pascual, R. \& Veredas, D. (2009). What pieces of limit order book information matter in explaining order choice by patient and impatient traders? Quantitative Finance, 9(5), 527545.

Pasquariello, P. \& Vega,C. (2007). Informed and strategic order flow in the bond markets. Review of Financial Studies, 20 (6), 1975-2019.

Pasquariello, P. \& Vega, C. (2012). Government Intervention and Strategic Trading in the U.S. Treasury Market (January 13, 2012). Available at SSRN:

https://ssrn.com/abstract=1769773

Pelizzon, L., Subrahmanyam, M.G., Tomio, D. \& Uno, J. (2016). Sovereign Credit Risk, Liquidity, and ECB Intervention: Deus ex Machina? Journal of Financial Economics, 122(1), 86-115.

Peng, C., Buldyrev, S.V., Havlin, S., Simons, M., Stanley, H.E. and Goldberger, A.L. (1994). Mosaic organization of DNA nucleotides. Physical Review E, 49(2), 1685.

Percival, D.B. \& Walden, A.T. (2006). Wavelet methods for time series analysis. Cambridge university press.

Perlin, M., Dufour, A. \& Brooks, C. (2010). A Microstructure Model for Spillover Effects in Price Discovery: A Study for the European Bond Market. SSRN Working Paper Series.

Plerou, V., Gopikrishnan, P. \& Stanley, H.E. (2005). Quantifying fluctuations in market liquidity: Analysis of the bid-ask spread. Physical Review E, 71(4), 046131.

Ranaldo, A. (2004). Order aggressiveness in limit order book markets. Journal of Financial Markets, 7(1), 53-74.

Shahiduzzaman-Quoreshi, A. M. M. (2014). A long-memory integer-valued time series model, INAFRIMA, for financial application. Quantitative Finance, 14(12), 2225-2235.

Teverovsky, V., Taqqu, M.S. \& Willinger, W. (1999). A critical look at Lo's modified R/S statistic. Journal of statistical Planning and Inference, 80(1), 211-227.

Weber, P. \& Rosenow, B. (2006). Large stock price changes: volume or liquidity? Quantitative Finance, 6(1), 7-14.

Weron, R. (2002). Estimating long-range dependence: finite sample properties and confidence intervals. Physica A: Statistical Mechanics and its Applications, 312(1), 285-299.

Weron, R. \& Przybylowicz, B. (2000). Hurst analysis of electricity price dynamics. Physica A: Statistical Mechanics and its Applications, 283(3), 462-468.

Wilinski, M., Cui, W., Brabazon, A. \& Hamill, P. (2015). An analysis of price impact functions of individual trades on the London stock exchange. Quantitative Finance, 15(10), 1727-1735. 
This is a post-peer-review, pre-copyedit version of an article published in Annals of Operations Research. The final authenticated version is available online at: $h$ ttps://doi.org/10.1007/s10479-0182850-y 
This is a post-peer-review, pre-copyedit version of an article published in Annals of Operations Research. The final authenticated version is available online at: $h$ ttps://doi.org/10.1007/s10479-018-2850-y

\section{Table 1. Monthly Volume for selected Benchmark Bond only.}

\begin{tabular}{ccccccccccccc}
\multicolumn{1}{l}{ Panel A: Average Number of Trades in a Month } \\
\hline Maturity & Platform & AU & BEL & GER & SPA & FIN & FRA & GRE & IRE & ITA & NET & POR \\
\hline \multirow{2}{*}{3 Years } & EBM & 8.131 & 10.130 & 34.569 & 28.125 & 15.535 & 22.083 & 23.757 & 7.519 & 74.972 & 18.889 & 23.145 \\
& MTS & 50.417 & 133.042 & 165.847 & 153.889 & 61.028 & 142.097 & 102.042 & 26.887 & 1192.917 & 135.694 & 154.042 \\
6 Years & EBM & 4.914 & 12.357 & 18.657 & 20.239 & 10.328 & 12.588 & 17.682 & 6.491 & 48.736 & 12.648 & 14.354 \\
& MTS & 33.458 & 160.847 & 90.375 & 115.806 & 51.181 & 90.986 & 80.423 & 19.333 & 773.222 & 81.500 & 137.366 \\
10 Years & EBM & 7.484 & 25.853 & 33.368 & 27.186 & 11.150 & 16.574 & 37.588 & 10.172 & 62.431 & 14.177 & 23.762 \\
& MTS & 54.431 & 248.403 & 96.833 & 205.194 & 57.236 & 99.750 & 192.556 & 31.843 & 1201.986 & 64.417 & 190.058
\end{tabular}

\begin{tabular}{cccccccccccccc}
\multicolumn{1}{l}{ Panel B: Average Dollar Volume in a Month (Billion Euro) } \\
\hline Maturity & Platform & AU & BEL & GER & SPA & FIN & FRA & GRE & IRE & ITA & NET & POR \\
\hline \multirow{2}{*}{3 Years } & EBM & 7,403 & 8,408 & 26,981 & 22,972 & 13,717 & 19,115 & 17,180 & 5,915 & 48,137 & 18,103 & 19,952 \\
& MTS & 47,124 & 125,625 & 135,939 & 141,158 & 57,713 & 124,255 & 70,100 & 20,005 & 749,031 & 137,215 & 142,256 \\
\multirow{2}{*}{6 Years } & EBM & 4,032 & 10,064 & 12,390 & 16,008 & 9,319 & 9,099 & 12,579 & 4,746 & 30,845 & 12,426 & 12,069 \\
& MTS & 28,797 & 145,843 & 61,556 & 103,319 & 49,308 & 70,371 & 53,123 & 14,190 & 478,046 & 82,336 & 126,453 \\
\multirow{2}{*}{10 Years } & EBM & 6,131 & 20,479 & 21,080 & 19,509 & 9,663 & 11,454 & 29,251 & 7,710 & 37,210 & 13,091 & 19,542 \\
& MTS & 45,469 & 217,232 & 61,232 & 170,810 & 54,459 & 79,392 & 140,350 & 21,333 & 643,776 & 62,591 & 170,416
\end{tabular}

Panel C: Average Trading Volume in a Month (Million Contract)

\begin{tabular}{ccccccccccccc} 
Maturity & Platform & AU & BEL & GER & SPA & FIN & FRA & GRE & IRE & ITA & NET & POR \\
\hline \multirow{2}{*}{ 3 Years } & EBM & 71.574 & 82.667 & 269.583 & 228.528 & 133.845 & 188.278 & 171.186 & 58.880 & 477.556 & 179.132 & 196.169 \\
& MTS & 455.542 & 1218.583 & 1347.153 & 1397.924 & 561.167 & 1207.431 & 699.438 & 199.347 & 7431.049 & 1330.347 & 1402.396 \\
6 Years & EBM & 38.957 & 98.243 & 121.582 & 157.164 & 89.604 & 88.956 & 122.318 & 46.073 & 301.229 & 119.296 & 116.469 \\
& MTS & 278.597 & 1421.222 & 602.694 & 1020.583 & 473.139 & 684.479 & 521.493 & 138.051 & 4678.646 & 785.035 & 1216.366 \\
\multirow{3}{*}{ 10 Years } & EBM & 60.194 & 207.037 & 214.000 & 194.857 & 95.942 & 114.353 & 297.485 & 75.867 & 369.049 & 130.403 & 198.198 \\
& MTS & 447.951 & 2164.229 & 616.271 & 1696.660 & 532.903 & 780.931 & 1404.361 & 215.529 & 6391.167 & 614.167 & 1711.442
\end{tabular}

Note: in this table, AU stands for Austria; BEL stands for Belgium; GER stands for German; SPA stands for Spain; FIN stands for Finland; FRA stands for France; GRE stands for Greece; IRE stands for Ireland; ITA stands for Italy; NET stands for Netherlands and POR stands for Portugal while EBM stands for EruoMTS platform and MTS stands for local MTS platform. 
This is a post-peer-review, pre-copyedit version of an article published in Annals of Operations Research. The final authenticated version is available online at: $h$ ttps://doi.org/10.1007/s10479-018-2850-y

\section{Table 2. Summary Statistics of MTS: Full and Sub-period.}

\begin{tabular}{|c|c|c|c|c|c|c|c|c|c|c|c|c|c|}
\hline Maturity & & Statistics & AU & BEL & GER & SPA & FIN & FRA & GRE & IRE & ITA & NET & POR \\
\hline \multirow[t]{3}{*}{3 Years } & & Mean & 0.1987 & 0.1548 & 0.0634 & 0.2016 & 0.1093 & 0.1116 & 3.5750 & 2.3589 & 0.1297 & 0.0612 & 2.3167 \\
\hline & & Std & 0.2200 & 0.1897 & 0.0812 & 0.2401 & 0.1315 & 0.1237 & 4.6697 & 4.0512 & 0.1810 & 0.0866 & 4.0380 \\
\hline & & Median & 0.1307 & 0.0930 & 0.0459 & 0.1022 & 0.0652 & 0.0710 & 0.2556 & 0.2551 & 0.0734 & 0.0366 & 0.1265 \\
\hline \multirow[t]{3}{*}{6 Years } & & Mean & 0.3199 & 0.2281 & 0.0831 & 0.2748 & 0.1903 & 0.1800 & 3.9146 & 3.2924 & 0.1789 & 0.1051 & 2.7761 \\
\hline & & Std & 0.3005 & 0.2467 & 0.1086 & 0.2875 & 0.2089 & 0.1880 & 4.7614 & 4.5358 & 0.2082 & 0.1210 & 4.2984 \\
\hline & & Median & 0.2461 & 0.1380 & 0.0573 & 0.1635 & 0.1170 & 0.1159 & 0.3314 & 0.3405 & 0.1095 & 0.0663 & 0.2130 \\
\hline \multirow[t]{3}{*}{10 Years } & & Mean & 0.3713 & 0.2497 & 0.0873 & 0.3121 & 0.2213 & 0.1964 & 3.8253 & 3.5935 & 0.2200 & 0.1231 & 3.1608 \\
\hline & & Std & 0.3310 & 0.2588 & 0.1063 & 0.3136 & 0.2624 & 0.1895 & 4.7267 & 4.6354 & 0.2461 & 0.1301 & 4.4847 \\
\hline & & Median & 0.2839 & 0.1611 & 0.0636 & 0.1788 & 0.1321 & 0.1438 & 0.3663 & 0.4183 & 0.1349 & 0.0810 & 0.2665 \\
\hline \multicolumn{14}{|c|}{ Panel B: Subperiod } \\
\hline Maturity & Subperiod & Statistics & $\mathbf{A U}$ & BEL & GER & SPA & FIN & FRA & GRE & IRE & ITA & NET & POR \\
\hline \multirow[t]{4}{*}{3 Years } & PRE & Mean & 0.0259 & 0.0201 & 0.0205 & 0.0205 & 0.0196 & 0.0308 & 0.0295 & 0.0247 & 0.0176 & 0.0218 & 0.0209 \\
\hline & GFC & Mean & 0.1376 & 0.1307 & 0.0804 & 0.1635 & 0.1201 & 0.1370 & 0.9372 & 0.1607 & 0.0815 & 0.0811 & 0.6092 \\
\hline & EDC1 & Mean & 0.2596 & 0.1403 & 0.0755 & 0.1788 & 0.1693 & 0.1312 & 3.1606 & 0.8211 & 0.1341 & 0.0703 & 0.8247 \\
\hline & EDC2 & Mean & 0.3650 & 0.3116 & 0.0782 & 0.4206 & 0.1352 & 0.1476 & 9.5950 & 7.6920 & 0.2728 & 0.0725 & 7.1366 \\
\hline \multirow[t]{4}{*}{6 Years } & PRE & Mean & 0.0339 & 0.0306 & 0.0296 & 0.0275 & 0.0268 & 0.0482 & 0.0437 & 0.0315 & 0.0279 & 0.0306 & 0.0340 \\
\hline & GFC & Mean & 0.2845 & 0.1891 & 0.1066 & 0.2519 & 0.2060 & 0.2280 & 1.4346 & 1.4082 & 0.1351 & 0.1271 & 0.6888 \\
\hline & EDC1 & Mean & 0.5012 & 0.2080 & 0.0999 & 0.2863 & 0.3068 & 0.2286 & 3.7841 & 1.4020 & 0.2054 & 0.1442 & 1.3313 \\
\hline & EDC2 & Mean & 0.4729 & 0.4605 & 0.0979 & 0.5140 & 0.2351 & 0.2197 & 9.8826 & 8.9724 & 0.3367 & 0.1231 & 8.3111 \\
\hline \multirow[t]{4}{*}{10 Years } & PRE & Mean & 0.0452 & 0.0351 & 0.0385 & 0.0322 & 0.0313 & 0.0499 & 0.0546 & 0.0402 & 0.0379 & 0.0375 & 0.0448 \\
\hline & GFC & Mean & 0.3435 & 0.2258 & 0.1119 & 0.2626 & 0.2770 & 0.2429 & 1.3344 & 1.8466 & 0.2034 & 0.1506 & 1.0052 \\
\hline & EDC1 & Mean & 0.5817 & 0.2366 & 0.1019 & 0.3315 & 0.3618 & 0.2158 & 3.3808 & 1.8642 & 0.2273 & 0.1680 & 1.4902 \\
\hline & EDC2 & Mean & 0.5315 & 0.4788 & 0.0984 & 0.5992 & 0.2359 & 0.2739 & 9.9587 & 9.7904 & 0.3966 & 0.1420 & 9.2781 \\
\hline
\end{tabular}

Note: in this table, AU stands for Austria; BEL stands for Belgium; GER stands for German; SPA stands for Spain; FIN stands for Finland; FRA stands for France; GRE stands for Greece; IRE stands for Ireland; ITA stands for Italy; NET stands for Netherlands and POR stands for Portugal 
This is a post-peer-review, pre-copyedit version of an article published in Annals of Operations Research. The final authenticated version is available online at: https://doi.org/10.1007/s10479-018-2850-y

\section{Table 3. Hill tail-index estimation of MTS.}

\begin{tabular}{lcccccccccccc} 
Maturity & $\begin{array}{c}\text { Cut off } \\
\text { point }\end{array}$ & AU & BEL & GER & SPA & FIN & FRA & GRE & IRE & ITA & NET & POR \\
\hline \multirow{2}{*}{ 3 Years } & $0.5 \%$ & 0.052 & 0.057 & 0.307 & 0.039 & 0.149 & 0.175 & 0.310 & 0.938 & 0.070 & 0.268 & 1.113 \\
& $1.0 \%$ & 0.105 & 0.102 & 0.417 & 0.067 & 0.192 & 0.206 & 1.306 & 0.506 & 0.115 & 0.335 & 0.583 \\
& $1.5 \%$ & 0.124 & 0.142 & 0.456 & 0.096 & 0.224 & 0.226 & 1.106 & 0.374 & 0.169 & 0.342 & 0.415 \\
& & & & & & & & & & & \\
6 Years & $0.5 \%$ & 0.015 & 0.041 & 0.160 & 0.013 & 0.042 & 0.054 & 0.146 & 1.008 & 0.056 & 0.155 & 1.214 \\
& $1.0 \%$ & 0.033 & 0.068 & 0.304 & 0.039 & 0.081 & 0.096 & 0.369 & 0.546 & 0.101 & 0.238 & 0.629 \\
& $1.5 \%$ & 0.052 & 0.096 & 0.406 & 0.059 & 0.109 & 0.128 & 0.790 & 0.378 & 0.131 & 0.288 & 0.448 \\
& & & & & & & & & & & \\
10 Years & $0.5 \%$ & 0.018 & 0.028 & 0.172 & 0.019 & 0.020 & 0.052 & 0.403 & 0.787 & 0.036 & 0.135 & 0.668 \\
& $1.0 \%$ & 0.036 & 0.054 & 0.281 & 0.034 & 0.042 & 0.087 & 1.363 & 0.439 & 0.068 & 0.222 & 0.359 \\
& $1.5 \%$ & 0.054 & 0.076 & 0.408 & 0.048 & 0.060 & 0.115 & 0.944 & 0.343 & 0.095 & 0.255 & 0.269
\end{tabular}

Note: in this table, AU stands for Austria; BEL stands for Belgium; GER stands for German; SPA stands for Spain; FIN stands for Finland; FRA stands for France; GRE stands for Greece; IRE stands for Ireland; ITA stands for Italy; NET stands for Netherlands and POR stands for Portugal. 
This is a post-peer-review, pre-copyedit version of an article published in Annals of Operations Research. The final authenticated version is available online at: https://doi.org/10.1007/s10479-0182850-y

Figure 1. The Curves of $q H(q)$ as a function of $q$ of $3 Y$-Sovereign Bond in 1 minute interval.

- $\quad$ MTS

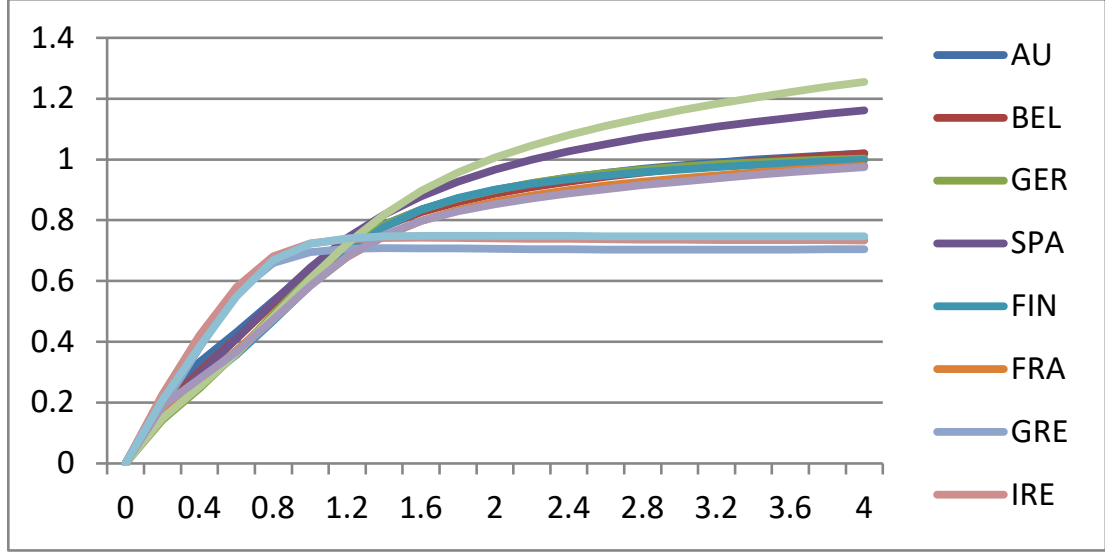

- $\quad$ EBM

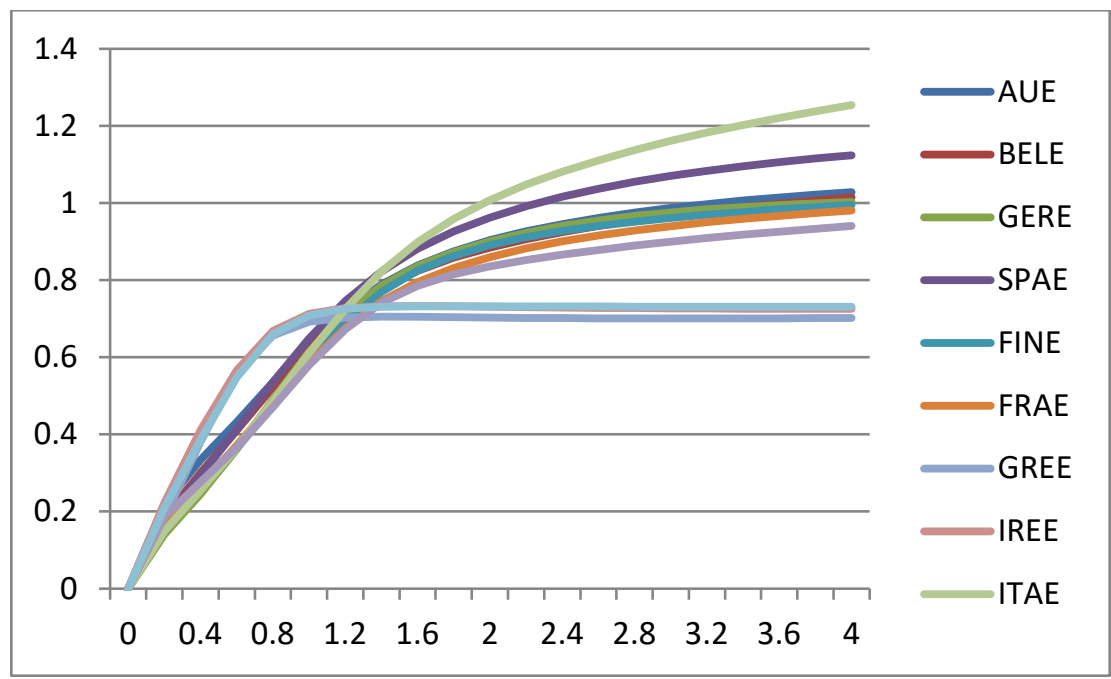


This is a post-peer-review, pre-copyedit version of an article published in Annals of Operations Research. The final authenticated version is available online at: $h$ ttps://doi.org/10.1007/s10479-018-2850-y

Table 4. Hurst Index Estimation (1 minute interval) of MTS: Full sample period.

\begin{tabular}{|c|c|c|c|c|c|c|c|c|c|c|c|c|}
\hline Maturity & Test & $\mathbf{A U}$ & BEL & GER & SPA & FIN & FRA & GRE & IRE & ITA & NET & POR \\
\hline \multirow[t]{2}{*}{3 Years } & $\mathrm{H}(1)$ & $\begin{array}{c}0.635 \\
(0.007)\end{array}$ & $\begin{array}{c}0.631 \\
(0.014)\end{array}$ & $\begin{array}{c}0.614 \\
(0.015)\end{array}$ & $\begin{array}{c}0.649 \\
(0.006)\end{array}$ & $\begin{array}{c}0.587 \\
(0.002)\end{array}$ & $\begin{array}{c}0.587 \\
(0.013)\end{array}$ & $\begin{array}{c}0.695 \\
(0.017)\end{array}$ & $\begin{array}{c}0.723 \\
(0.013)\end{array}$ & $\begin{array}{c}0.607 \\
(0.005)\end{array}$ & $\begin{array}{c}0.584 \\
(0.006)\end{array}$ & $\begin{array}{c}0.723 \\
(0.019)\end{array}$ \\
\hline & $\mathrm{H}(2)$ & $\begin{array}{c}0.450 \\
(0.010)\end{array}$ & $\begin{array}{c}0.443 \\
(0.017)\end{array}$ & $\begin{array}{l}0.450 \\
(0.02)\end{array}$ & $\begin{array}{c}0.481 \\
(0.008)\end{array}$ & $\begin{array}{c}0.450 \\
(0.011)\end{array}$ & $\begin{array}{c}0.430 \\
(0.018)\end{array}$ & $\begin{array}{c}0.353 \\
(0.008)\end{array}$ & $\begin{array}{c}0.370 \\
(0.006)\end{array}$ & $\begin{array}{l}0.503 \\
(0.02)\end{array}$ & $\begin{array}{c}0.426 \\
(0.014)\end{array}$ & $\begin{array}{c}0.374 \\
(0.010)\end{array}$ \\
\hline \multirow[t]{2}{*}{6 Years } & $\mathrm{H}(1)$ & $\begin{array}{c}0.607 \\
(0.006)\end{array}$ & $\begin{array}{c}0.600 \\
(0.013)\end{array}$ & $\begin{array}{c}0.577 \\
(0.011)\end{array}$ & $\begin{array}{c}0.608 \\
(0.005)\end{array}$ & $\begin{array}{c}0.586 \\
(0.006)\end{array}$ & $\begin{array}{c}0.609 \\
(0.014)\end{array}$ & $\begin{array}{c}0.649 \\
(0.016)\end{array}$ & $\begin{array}{c}0.677 \\
(0.012)\end{array}$ & $\begin{array}{c}0.578 \\
(0.006)\end{array}$ & $\begin{array}{c}0.560 \\
(0.003)\end{array}$ & $\begin{array}{c}0.683 \\
(0.005)\end{array}$ \\
\hline & $\mathrm{H}(2)$ & $\begin{array}{c}0.424 \\
(0.010)\end{array}$ & $\begin{array}{c}0.412 \\
(0.019)\end{array}$ & $\begin{array}{c}0.430 \\
(0.017)\end{array}$ & $\begin{array}{c}0.448 \\
(0.005)\end{array}$ & $\begin{array}{c}0.452 \\
(0.006)\end{array}$ & $\begin{array}{c}0.438 \\
(0.019)\end{array}$ & $\begin{array}{c}0.330 \\
(0.008)\end{array}$ & $\begin{array}{c}0.347 \\
(0.006)\end{array}$ & $\begin{array}{c}0.461 \\
(0.016)\end{array}$ & $\begin{array}{c}0.418 \\
(0.016)\end{array}$ & $\begin{array}{c}0.352 \\
(0.002)\end{array}$ \\
\hline \multirow[t]{2}{*}{10 Years } & $\mathrm{H}(1)$ & $\begin{array}{c}0.600 \\
(0.008)\end{array}$ & $\begin{array}{c}0.581 \\
(0.013)\end{array}$ & $\begin{array}{l}0.534 \\
(0.01)\end{array}$ & $\begin{array}{c}0.572 \\
(0.006)\end{array}$ & $\begin{array}{c}0.566 \\
(0.006)\end{array}$ & $\begin{array}{c}0.574 \\
(0.015)\end{array}$ & $\begin{array}{c}0.615 \\
(0.013)\end{array}$ & $\begin{array}{c}0.635 \\
(0.036)\end{array}$ & $\begin{array}{c}0.547 \\
(0.004)\end{array}$ & $\begin{array}{c}0.530 \\
(0.004)\end{array}$ & $\begin{array}{c}0.642 \\
(0.010)\end{array}$ \\
\hline & $\mathrm{H}(2)$ & $\begin{array}{c}0.428 \\
(0.011)\end{array}$ & $\begin{array}{c}0.397 \\
(0.019)\end{array}$ & $\begin{array}{c}0.397 \\
(0.020)\end{array}$ & $\begin{array}{c}0.426 \\
(0.005)\end{array}$ & $\begin{array}{c}0.432 \\
(0.007)\end{array}$ & $\begin{array}{c}0.398 \\
(0.018)\end{array}$ & $\begin{array}{c}0.313 \\
(0.007)\end{array}$ & $\begin{array}{c}0.322 \\
(0.019)\end{array}$ & $\begin{array}{c}0.444 \\
(0.013)\end{array}$ & $\begin{array}{c}0.382 \\
(0.016)\end{array}$ & $\begin{array}{c}0.331 \\
(0.005)\end{array}$ \\
\hline
\end{tabular}

Note: in this table, AU stands for Austria; BEL stands for Belgium; GER stands for German; SPA stands for Spain; FIN stands for Finland; FRA stands for France; GRE stands for Greece; IRE stands for Ireland; ITA stands for Italy; NET stands for Netherlands and POR stands for Portugal. 
This is a post-peer-review, pre-copyedit version of an article published in Annals of Operations Research. The final authenticated version is available online at: $h$ ttps://doi.org/10.1007/s10479-018-2850-y

\section{Table 5. The DCS Estimation of MTS.}

\begin{tabular}{|c|c|c|c|c|c|c|c|c|c|c|c|}
\hline $\begin{array}{l}\text { Panel A: } 3 \\
\text { Estimates }\end{array}$ & $\begin{array}{c}\text { s Maturity } \\
\text { AU }\end{array}$ & BEL & GER & SPA & FIN & FRA & GRE & IRE & ITA & NET & POR \\
\hline \multirow[t]{2}{*}{$\omega$} & -3.343 & -2.764 & -3.425 & -2.625 & -2.928 & -3.287 & -3.100 & -3.297 & -1.156 & -2.473 & -2.180 \\
\hline & $(>10.000)$ & $(0.001)$ & (0.108) & $(0.001)$ & $(0.017)$ & $(0.266)$ & $(>10.000)$ & (0.179) & $(0.000)$ & $(0.011)$ & $(0.001)$ \\
\hline \multirow[t]{2}{*}{$\varphi_{1}$} & 1.000 & 0.997 & 1.000 & 0.998 & 0.997 & 1.000 & 1.000 & 1.000 & 1.000 & 1.000 & 1.000 \\
\hline & $(0.056)$ & $(0.000)$ & $(0.000)$ & $(0.000)$ & $(0.000)$ & $(0.000)$ & $(>10.000)$ & $(0.000)$ & $(0.000)$ & $(0.000)$ & $(0.000)$ \\
\hline \multirow[t]{2}{*}{$\varphi_{2}$} & 0.965 & 0.996 & 0.976 & 0.998 & 0.997 & 0.967 & 0.982 & 0.956 & 0.981 & 0.975 & 0.969 \\
\hline & (3.872) & $(0.000)$ & $(0.000)$ & $(0.000)$ & $(0.000)$ & $(0.000)$ & $(>10.000)$ & $(0.001)$ & $(0.000)$ & $(0.006)$ & $(0.000)$ \\
\hline \multirow[t]{2}{*}{$\theta_{1}$} & 0.006 & 0.058 & 0.006 & -0.873 & -0.057 & 0.005 & 0.005 & 0.005 & 0.006 & 0.005 & 0.007 \\
\hline & (1.678) & $(0.000)$ & $(0.000)$ & $(0.000)$ & $(0.004)$ & $(0.000)$ & $(>10.000)$ & $(0.001)$ & $(0.000)$ & $(0.018)$ & $(0.001)$ \\
\hline \multirow[t]{2}{*}{$\theta_{2}$} & 0.108 & 0.064 & 0.096 & 0.969 & 0.168 & 0.097 & 0.151 & 0.138 & 0.131 & 0.125 & 0.150 \\
\hline & $(0.081)$ & $(0.000)$ & $(0.000)$ & $(0.000)$ & $(0.004)$ & $(0.000)$ & $(>10.000)$ & $(0.001)$ & $(0.000)$ & $(0.025)$ & $(0.001)$ \\
\hline Shape & $\begin{array}{c}28.268 \\
(>10.000)\end{array}$ & $\begin{array}{l}26.044 \\
(0.005)\end{array}$ & $\begin{array}{l}30.984 \\
(0.024)\end{array}$ & $\begin{array}{l}33.845 \\
(0.006)\end{array}$ & $\begin{array}{l}27.270 \\
(0.020)\end{array}$ & $\begin{array}{l}30.523 \\
(0.028)\end{array}$ & $\begin{array}{c}21.040 \\
(>10.000)\end{array}$ & $\begin{array}{l}25.155 \\
(0.048)\end{array}$ & $\begin{array}{l}21.712 \\
(0.002)\end{array}$ & $\begin{array}{l}22.927 \\
(0.020)\end{array}$ & $\begin{array}{l}21.091 \\
(0.039)\end{array}$ \\
\hline
\end{tabular}


This is a post-peer-review, pre-copyedit version of an article published in Annals of Operations Research. The final authenticated version is available online at: $h$ ttps://doi.org/10.1007/s10479-018-2850-y

\begin{tabular}{|c|c|c|c|c|c|c|c|c|c|c|c|}
\hline Estimates & $\mathbf{A U}$ & BEL & GER & SPA & FIN & FRA & GRE & IRE & ITA & NET & POR \\
\hline$\omega$ & $\begin{array}{l}-2.175 \\
(0.009)\end{array}$ & $\begin{array}{l}-2.355 \\
(0.568)\end{array}$ & $\begin{array}{l}-2.461 \\
(0.000)\end{array}$ & $\begin{array}{c}-3.292 \\
(>10.000)\end{array}$ & $\begin{array}{l}-2.145 \\
(0.000)\end{array}$ & $\begin{array}{l}-1.679 \\
(0.411)\end{array}$ & $\begin{array}{c}-2.861 \\
(>10.000)\end{array}$ & $\begin{array}{l}-3.064 \\
(0.148)\end{array}$ & $\begin{array}{l}-1.318 \\
(0.023)\end{array}$ & $\begin{array}{c}-3.291 \\
(>10.000)\end{array}$ & $\begin{array}{l}-3.753 \\
(0.012)\end{array}$ \\
\hline$\varphi_{1}$ & $\begin{array}{c}0.997 \\
(0.000)\end{array}$ & $\begin{array}{c}0.997 \\
(0.001)\end{array}$ & $\begin{array}{c}1.000 \\
(0.000)\end{array}$ & $\begin{array}{c}1.000 \\
(7.837)\end{array}$ & $\begin{array}{c}1.000 \\
(0.000)\end{array}$ & $\begin{array}{c}1.000 \\
(0.000)\end{array}$ & $\begin{array}{c}1.000 \\
(0.020)\end{array}$ & $\begin{array}{c}1.000 \\
(0.000)\end{array}$ & $\begin{array}{c}0.997 \\
(0.001)\end{array}$ & $\begin{array}{c}1.000 \\
(0.197)\end{array}$ & $\begin{array}{c}1.000 \\
(0.000)\end{array}$ \\
\hline$\varphi_{2}$ & $\begin{array}{c}0.997 \\
(0.000)\end{array}$ & $\begin{array}{c}0.997 \\
(0.001)\end{array}$ & $\begin{array}{c}0.968 \\
(0.000)\end{array}$ & $\begin{array}{c}0.969 \\
(>10.000)\end{array}$ & $\begin{array}{c}0.965 \\
(0.000)\end{array}$ & $\begin{array}{c}0.966 \\
(0.090)\end{array}$ & $\begin{array}{c}0.982 \\
(0.195)\end{array}$ & $\begin{array}{c}0.950 \\
(0.000)\end{array}$ & $\begin{array}{c}0.997 \\
(0.000)\end{array}$ & $\begin{array}{c}0.975 \\
(0.801)\end{array}$ & $\begin{array}{c}0.971 \\
(0.000)\end{array}$ \\
\hline$\theta_{1}$ & $\begin{array}{l}-4.920 \\
(0.010)\end{array}$ & $\begin{array}{l}-0.178 \\
(1.227)\end{array}$ & $\begin{array}{c}0.004 \\
(0.000)\end{array}$ & $\begin{array}{c}0.006 \\
(>10.000)\end{array}$ & $\begin{array}{c}0.006 \\
(0.000)\end{array}$ & $\begin{array}{c}0.006 \\
(0.229)\end{array}$ & $\begin{array}{c}0.006 \\
(1.901)\end{array}$ & $\begin{array}{c}0.008 \\
(0.000)\end{array}$ & $\begin{array}{l}-0.010 \\
(0.004)\end{array}$ & $\begin{array}{c}0.005 \\
(3.926)\end{array}$ & $\begin{array}{c}0.006 \\
(0.000)\end{array}$ \\
\hline$\theta_{2}$ & $\begin{array}{c}5.032 \\
(0.019)\end{array}$ & $\begin{array}{c}0.288 \\
(0.842)\end{array}$ & $\begin{array}{c}0.116 \\
(0.000)\end{array}$ & $\begin{array}{c}0.091 \\
(>10.000)\end{array}$ & $\begin{array}{c}0.116 \\
(0.000)\end{array}$ & $\begin{array}{c}0.096 \\
(0.289)\end{array}$ & $\begin{array}{c}0.157 \\
(1.201)\end{array}$ & $\begin{array}{c}0.168 \\
(0.000)\end{array}$ & $\begin{array}{c}0.140 \\
(0.002)\end{array}$ & $\begin{array}{c}0.121 \\
(4.432)\end{array}$ & $\begin{array}{c}0.131 \\
(0.000)\end{array}$ \\
\hline Shape & $\begin{array}{l}28.897 \\
(0.165)\end{array}$ & $\begin{array}{l}28.021 \\
(0.021)\end{array}$ & $\begin{array}{l}24.325 \\
(0.001)\end{array}$ & $\begin{array}{c}32.913 \\
(>10.000)\end{array}$ & $\begin{array}{l}23.655 \\
(0.001)\end{array}$ & $\begin{array}{l}31.002 \\
(0.580)\end{array}$ & $\begin{array}{c}19.186 \\
(>10.000)\end{array}$ & $\begin{array}{l}18.970 \\
(0.022)\end{array}$ & $\begin{array}{l}21.608 \\
(0.015)\end{array}$ & $\begin{array}{c}22.572 \\
(>10.000)\end{array}$ & $\begin{array}{l}22.442 \\
(0.022)\end{array}$ \\
\hline
\end{tabular}


This is a post-peer-review, pre-copyedit version of an article published in Annals of Operations Research. The final authenticated version is available online at: https://doi.org/10.1007/s10479-018-2850-y

\begin{tabular}{|c|c|c|c|c|c|c|c|c|c|c|c|}
\hline Estimates & AU & BEL & GER & SPA & FIN & FRA & GRE & IRE & ITA & NET & POR \\
\hline$\omega$ & $\begin{array}{l}-2.727 \\
(0.128)\end{array}$ & $\begin{array}{l}-2.264 \\
(0.001)\end{array}$ & $\begin{array}{l}-3.177 \\
(0.192)\end{array}$ & $\begin{array}{c}-3.001 \\
(9.380)\end{array}$ & $\begin{array}{l}-2.083 \\
(0.011)\end{array}$ & $\begin{array}{l}-3.001 \\
(0.000)\end{array}$ & $\begin{array}{l}-2.110 \\
(0.003)\end{array}$ & $\begin{array}{l}-2.855 \\
(0.046)\end{array}$ & $\begin{array}{l}-0.780 \\
(0.000)\end{array}$ & $\begin{array}{c}-2.402 \\
(5.479)\end{array}$ & $\begin{array}{l}-3.004 \\
(0.095)\end{array}$ \\
\hline$\varphi_{1}$ & $\begin{array}{c}1.000 \\
(0.000)\end{array}$ & $\begin{array}{c}0.997 \\
(0.000)\end{array}$ & $\begin{array}{c}1.000 \\
(0.000)\end{array}$ & $\begin{array}{c}1.000 \\
(0.000)\end{array}$ & $\begin{array}{c}1.000 \\
(0.000)\end{array}$ & $\begin{array}{c}1.000 \\
(0.000)\end{array}$ & $\begin{array}{c}1.000 \\
(0.000)\end{array}$ & $\begin{array}{c}1.000 \\
(0.000)\end{array}$ & $\begin{array}{c}1.000 \\
(0.000)\end{array}$ & $\begin{array}{c}0.993 \\
(0.001)\end{array}$ & $\begin{array}{r}1.000 \\
(0.000)\end{array}$ \\
\hline$\varphi_{2}$ & $\begin{array}{c}0.969 \\
(0.005)\end{array}$ & $\begin{array}{c}0.997 \\
(0.000)\end{array}$ & $\begin{array}{c}0.970 \\
(0.001)\end{array}$ & $\begin{array}{c}1.000 \\
(0.000)\end{array}$ & $\begin{array}{c}0.964 \\
(0.000)\end{array}$ & $\begin{array}{c}1.000 \\
(0.000)\end{array}$ & $\begin{array}{c}0.981 \\
(0.000)\end{array}$ & $\begin{array}{c}0.967 \\
(0.000)\end{array}$ & $\begin{array}{c}0.977 \\
(0.000)\end{array}$ & $\begin{array}{c}0.993 \\
(0.000)\end{array}$ & $\begin{array}{c}0.976 \\
(0.000)\end{array}$ \\
\hline$\theta_{1}$ & $\begin{array}{c}0.004 \\
(0.002)\end{array}$ & $\begin{array}{l}-0.727 \\
(0.000)\end{array}$ & $\begin{array}{c}0.005 \\
(0.002)\end{array}$ & $\begin{array}{c}-0.955 \\
(3.070)\end{array}$ & $\begin{array}{c}0.006 \\
(0.007)\end{array}$ & $\begin{array}{l}-2.181 \\
(0.000)\end{array}$ & $\begin{array}{c}0.005 \\
(0.002)\end{array}$ & $\begin{array}{c}0.007 \\
(0.000)\end{array}$ & $\begin{array}{c}0.005 \\
(0.000)\end{array}$ & $\begin{array}{l}-0.017 \\
(0.055)\end{array}$ & $\begin{array}{c}0.005 \\
(0.000)\end{array}$ \\
\hline$\theta_{2}$ & $\begin{array}{c}0.087 \\
(0.002)\end{array}$ & $\begin{array}{c}0.824 \\
(0.001)\end{array}$ & $\begin{array}{c}0.115 \\
(0.004)\end{array}$ & $\begin{array}{c}1.050 \\
(4.542)\end{array}$ & $\begin{array}{c}0.113 \\
(0.006)\end{array}$ & $\begin{array}{c}2.285 \\
(0.000)\end{array}$ & $\begin{array}{c}0.167 \\
(0.002)\end{array}$ & $\begin{array}{c}0.141 \\
(0.000)\end{array}$ & $\begin{array}{c}0.122 \\
(0.000)\end{array}$ & $\begin{array}{c}0.142 \\
(0.099)\end{array}$ & $\begin{array}{c}0.113 \\
(0.000)\end{array}$ \\
\hline Shape & $\begin{array}{c}34.524 \\
(0.043)\end{array}$ & $\begin{array}{l}30.424 \\
(0.023)\end{array}$ & $\begin{array}{c}23.748 \\
(0.011)\end{array}$ & $\begin{array}{c}32.517 \\
(65.155)\end{array}$ & $\begin{array}{l}23.887 \\
(0.009)\end{array}$ & $\begin{array}{l}30.737 \\
(0.000)\end{array}$ & $\begin{array}{l}17.462 \\
(0.018)\end{array}$ & $\begin{array}{l}24.332 \\
(0.024)\end{array}$ & $\begin{array}{l}22.432 \\
(0.001)\end{array}$ & $\begin{array}{c}22.032 \\
(2.343)\end{array}$ & $\begin{array}{l}25.083 \\
(0.022)\end{array}$ \\
\hline
\end{tabular}

Note: in this table, AU stands for Austria; BEL stands for Belgium; GER stands for German; SPA stands for Spain; FIN stands for Finland; FRA stands for France; GRE stands for Greece; IRE stands for Ireland; ITA stands for Italy; NET stands for Netherlands and POR stands for Portugal. 
This is a post-peer-review, pre-copyedit version of an article published in Annals of Operations Research. The final authenticated version is available online at: $h$ ttps://doi.org/10.1007/s10479-018-2850-y

\section{Table 6a. Hurst Index Estimation (1 minute interval) of MTS: Sub-periods.}

\begin{tabular}{|c|c|c|c|c|c|c|c|c|c|c|c|c|}
\hline Test & Subperiod & $\mathbf{A U}$ & BEL & GER & SPA & FIN & FRA & GRE & IRE & ITA & NET & POR \\
\hline \multirow[t]{8}{*}{$\mathrm{H}(1)$} & PRE & 0.378 & 0.315 & 0.348 & 0.348 & 0.335 & 0.394 & 0.581 & 0.495 & 0.327 & 0.355 & 0.374 \\
\hline & & $(0.018)$ & $(0.020)$ & $(0.012)$ & $(0.011)$ & $(0.014)$ & $(0.018)$ & $(0.014)$ & $(0.019)$ & $(0.022)$ & $(0.022)$ & (0.019) \\
\hline & GFC & 0.495 & 0.532 & 0.562 & 0.584 & 0.446 & 0.543 & 0.747 & 0.506 & 0.395 & 0.520 & 0.622 \\
\hline & & $(0.008)$ & (0.009) & $(0.025)$ & $(0.003)$ & $(0.008)$ & $(0.013)$ & $(0.026)$ & (0.009) & $(0.001)$ & $(0.007)$ & $(0.031)$ \\
\hline & EDC1 & 0.631 & 0.643 & 0.611 & 0.636 & 0.593 & 0.571 & 0.711 & 0.745 & 0.589 & 0.586 & 0.766 \\
\hline & & $(0.014)$ & (0.009) & $(0.018)$ & (0.009) & $(0.008)$ & $(0.014)$ & $(0.018)$ & (0.019) & $(0.011)$ & $(0.004)$ & $(0.021)$ \\
\hline & EDC2 & 0.716 & 0.673 & 0.693 & 0.684 & 0.671 & 0.658 & 0.630 & 0.729 & 0.681 & 0.641 & 0.703 \\
\hline & & $(0.006)$ & $(0.022)$ & $(0.015)$ & $(0.010)$ & $(0.008)$ & $(0.017)$ & $(0.012)$ & $(0.016)$ & $(0.006)$ & $(0.008)$ & $(0.010)$ \\
\hline \multirow[t]{8}{*}{$\mathrm{H}(2)$} & PRE & 0.478 & 0.216 & 0.374 & 0.457 & 0.266 & 0.339 & 0.459 & 0.474 & 0.329 & 0.268 & 0.297 \\
\hline & & $(0.017)$ & $(0.006)$ & $(0.033)$ & $(0.021)$ & $(0.003)$ & $(0.019)$ & $(0.022)$ & $(0.031)$ & $(0.063)$ & $(0.038)$ & $(0.004)$ \\
\hline & GFC & 0.413 & 0.422 & 0.453 & 0.460 & 0.379 & 0.464 & 0.404 & 0.363 & 0.380 & 0.387 & 0.333 \\
\hline & & $(0.017)$ & $(0.022)$ & $(0.034)$ & $(0.009)$ & $(0.041)$ & $(0.022)$ & $(0.014)$ & $(0.020)$ & $(0.029)$ & $(0.009)$ & $(0.036)$ \\
\hline & EDC1 & 0.422 & 0.460 & 0.426 & 0.416 & 0.427 & 0.378 & 0.361 & 0.389 & 0.480 & 0.407 & 0.399 \\
\hline & & $(0.007)$ & $(0.005)$ & $(0.016)$ & $(0.004)$ & $(0.009)$ & $(0.014)$ & $(0.009)$ & $(0.008)$ & $(0.024)$ & $(0.005)$ & $(0.010)$ \\
\hline & EDC2 & 0.484 & 0.444 & 0.482 & 0.508 & 0.486 & 0.459 & 0.310 & 0.369 & 0.537 & 0.452 & 0.360 \\
\hline & & $(0.010)$ & $(0.023)$ & $(0.019)$ & $(0.011)$ & $(0.007)$ & $(0.022)$ & $(0.006)$ & $(0.007)$ & $(0.010)$ & $(0.020)$ & $(0.004)$ \\
\hline
\end{tabular}


This is a post-peer-review, pre-copyedit version of an article published in Annals of Operations Research. The final authenticated version is available online at: https://doi.org/10.1007/s10479-018-2850-y

\begin{tabular}{|c|c|c|c|c|c|c|c|c|c|c|c|c|}
\hline Test & Subperiod & AU & BEL & GER & SPA & FIN & FRA & GRE & IRE & ITA & NET & POR \\
\hline \multirow[t]{4}{*}{$\mathrm{H}(1)$} & PRE & $\begin{array}{c}0.362 \\
(0.009)\end{array}$ & $\begin{array}{c}0.336 \\
(0.010)\end{array}$ & $\begin{array}{c}0.324 \\
(0.005)\end{array}$ & $\begin{array}{c}0.328 \\
(0.003)\end{array}$ & $\begin{array}{c}0.300 \\
(0.008)\end{array}$ & $\begin{array}{c}0.455 \\
(0.003)\end{array}$ & $\begin{array}{c}0.483 \\
(0.029)\end{array}$ & $\begin{array}{c}0.293 \\
(0.019)\end{array}$ & $\begin{array}{c}0.308 \\
(0.011)\end{array}$ & $\begin{array}{c}0.318 \\
(0.007)\end{array}$ & $\begin{array}{c}0.460 \\
(0.008)\end{array}$ \\
\hline & GFC & $\begin{array}{c}0.545 \\
(0.010)\end{array}$ & $\begin{array}{c}0.558 \\
(0.009)\end{array}$ & $\begin{array}{c}0.517 \\
(0.019)\end{array}$ & $\begin{array}{c}0.633 \\
(0.013)\end{array}$ & $\begin{array}{c}0.472 \\
(0.003)\end{array}$ & $\begin{array}{c}0.613 \\
(0.024)\end{array}$ & $\begin{array}{c}0.703 \\
(0.022)\end{array}$ & $\begin{array}{c}0.639 \\
(0.022)\end{array}$ & $\begin{array}{c}0.412 \\
(0.008)\end{array}$ & $\begin{array}{c}0.546 \\
(0.006)\end{array}$ & $\begin{array}{c}0.619 \\
(0.010)\end{array}$ \\
\hline & EDC1 & $\begin{array}{c}0.627 \\
(0.010)\end{array}$ & $\begin{array}{c}0.609 \\
(0.006)\end{array}$ & $\begin{array}{c}0.595 \\
(0.017)\end{array}$ & $\begin{array}{c}0.606 \\
(0.004)\end{array}$ & $\begin{array}{c}0.608 \\
(0.003)\end{array}$ & $\begin{array}{c}0.633 \\
(0.015)\end{array}$ & $\begin{array}{c}0.665 \\
(0.016)\end{array}$ & $\begin{array}{c}0.658 \\
(0.008)\end{array}$ & $\begin{array}{c}0.592 \\
(0.009)\end{array}$ & $\begin{array}{c}0.561 \\
(0.002)\end{array}$ & $\begin{array}{c}0.726 \\
(0.009)\end{array}$ \\
\hline & EDC2 & $\begin{array}{c}0.666 \\
(0.003)\end{array}$ & $\begin{array}{c}0.635 \\
(0.022)\end{array}$ & $\begin{array}{c}0.628 \\
(0.008)\end{array}$ & $\begin{array}{c}0.629 \\
(0.007)\end{array}$ & $\begin{array}{c}0.660 \\
(0.010)\end{array}$ & $\begin{array}{c}0.615 \\
(0.013)\end{array}$ & $\begin{array}{c}0.573 \\
(0.014)\end{array}$ & $\begin{array}{c}0.705 \\
(0.014)\end{array}$ & $\begin{array}{c}0.625 \\
(0.011)\end{array}$ & $\begin{array}{c}0.609 \\
(0.006)\end{array}$ & $\begin{array}{c}0.640 \\
(0.006)\end{array}$ \\
\hline \multirow[t]{4}{*}{$\mathrm{H}(2)$} & PRE & $\begin{array}{c}0.314 \\
(0.008)\end{array}$ & $\begin{array}{c}0.276 \\
(0.002)\end{array}$ & $\begin{array}{c}0.388 \\
(0.033)\end{array}$ & $\begin{array}{c}0.468 \\
(0.020)\end{array}$ & $\begin{array}{c}0.465 \\
(0.017)\end{array}$ & $\begin{array}{c}0.404 \\
(0.008)\end{array}$ & $\begin{array}{c}0.298 \\
(0.033)\end{array}$ & $\begin{array}{c}0.172 \\
(0.006)\end{array}$ & $\begin{array}{c}0.373 \\
(0.046)\end{array}$ & $\begin{array}{c}0.464 \\
(0.013)\end{array}$ & $\begin{array}{c}0.482 \\
(0.019)\end{array}$ \\
\hline & GFC & $\begin{array}{c}0.400 \\
(0.012)\end{array}$ & $\begin{array}{c}0.413 \\
(0.017)\end{array}$ & $\begin{array}{c}0.429 \\
(0.021)\end{array}$ & $\begin{array}{c}0.401 \\
(0.012)\end{array}$ & $\begin{array}{c}0.370 \\
(0.016)\end{array}$ & $\begin{array}{c}0.447 \\
(0.023)\end{array}$ & $\begin{array}{c}0.379 \\
(0.013)\end{array}$ & $\begin{array}{c}0.353 \\
(0.014)\end{array}$ & $\begin{array}{c}0.296 \\
(0.013)\end{array}$ & $\begin{array}{c}0.393 \\
(0.011)\end{array}$ & $\begin{array}{c}0.370 \\
(0.041)\end{array}$ \\
\hline & EDC1 & $\begin{array}{c}0.394 \\
(0.008)\end{array}$ & $\begin{array}{c}0.440 \\
(0.011)\end{array}$ & $\begin{array}{c}0.416 \\
(0.016)\end{array}$ & $\begin{array}{c}0.421 \\
(0.002)\end{array}$ & $\begin{array}{c}0.421 \\
(0.008)\end{array}$ & $\begin{array}{c}0.441 \\
(0.015)\end{array}$ & $\begin{array}{c}0.337 \\
(0.008)\end{array}$ & $\begin{array}{c}0.333 \\
(0.003)\end{array}$ & $\begin{array}{c}0.469 \\
(0.015)\end{array}$ & $\begin{array}{c}0.408 \\
(0.008)\end{array}$ & $\begin{array}{c}0.376 \\
(0.003)\end{array}$ \\
\hline & EDC2 & $\begin{array}{c}0.474 \\
(0.010)\end{array}$ & $\begin{array}{c}0.402 \\
(0.025)\end{array}$ & $\begin{array}{c}0.447 \\
(0.021)\end{array}$ & $\begin{array}{c}0.482 \\
(0.007)\end{array}$ & $\begin{array}{c}0.490 \\
(0.005)\end{array}$ & $\begin{array}{c}0.439 \\
(0.020)\end{array}$ & $\begin{array}{c}0.282 \\
(0.008)\end{array}$ & $\begin{array}{c}0.356 \\
(0.006)\end{array}$ & $\begin{array}{c}0.486 \\
(0.009)\end{array}$ & $\begin{array}{c}0.435 \\
(0.022)\end{array}$ & $\begin{array}{c}0.325 \\
(0.002)\end{array}$ \\
\hline
\end{tabular}


This is a post-peer-review, pre-copyedit version of an article published in Annals of Operations Research. The final authenticated version is available online at: https://doi.org/10.1007/s10479-018-2850-y

\begin{tabular}{|c|c|c|c|c|c|c|c|c|c|c|c|c|}
\hline Test & Subperiod & AU & BEL & GER & SPA & FIN & FRA & GRE & IRE & ITA & NET & POR \\
\hline \multirow[t]{4}{*}{$\mathrm{H}(1)$} & PRE & $\begin{array}{c}0.425 \\
(0.003)\end{array}$ & $\begin{array}{c}0.328 \\
(0.001)\end{array}$ & $\begin{array}{c}0.372 \\
(0.007)\end{array}$ & $\begin{array}{c}0.350 \\
(0.001)\end{array}$ & $\begin{array}{c}0.306 \\
(0.003)\end{array}$ & $\begin{array}{c}0.412 \\
(0.006)\end{array}$ & $\begin{array}{c}0.590 \\
(0.014)\end{array}$ & $\begin{array}{c}0.445 \\
(0.007)\end{array}$ & $\begin{array}{c}0.348 \\
(0.006)\end{array}$ & $\begin{array}{c}0.325 \\
(0.006)\end{array}$ & $\begin{array}{c}0.292 \\
(0.017)\end{array}$ \\
\hline & GFC & $\begin{array}{c}0.554 \\
(0.011)\end{array}$ & $\begin{array}{c}0.584 \\
(0.011)\end{array}$ & $\begin{array}{c}0.553 \\
(0.023)\end{array}$ & $\begin{array}{c}0.588 \\
(0.007)\end{array}$ & $\begin{array}{c}0.536 \\
(0.009)\end{array}$ & $\begin{array}{c}0.579 \\
(0.027)\end{array}$ & $\begin{array}{c}0.678 \\
(0.022)\end{array}$ & $\begin{array}{c}0.664 \\
(0.041)\end{array}$ & $\begin{array}{c}0.485 \\
(0.003)\end{array}$ & $\begin{array}{c}0.538 \\
(0.010)\end{array}$ & $\begin{array}{c}0.621 \\
(0.020)\end{array}$ \\
\hline & EDC1 & $\begin{array}{c}0.635 \\
(0.017)\end{array}$ & $\begin{array}{c}0.580 \\
(0.009)\end{array}$ & $\begin{array}{c}0.545 \\
(0.014)\end{array}$ & $\begin{array}{c}0.573 \\
(0.005)\end{array}$ & $\begin{array}{c}0.584 \\
(0.003)\end{array}$ & $\begin{array}{c}0.574 \\
(0.014)\end{array}$ & $\begin{array}{c}0.641 \\
(0.017)\end{array}$ & $\begin{array}{c}0.624 \\
(0.039)\end{array}$ & $\begin{array}{c}0.562 \\
(0.006)\end{array}$ & $\begin{array}{c}0.535 \\
(0.002)\end{array}$ & $\begin{array}{c}0.696 \\
(0.011)\end{array}$ \\
\hline & EDC2 & $\begin{array}{c}0.621 \\
(0.003)\end{array}$ & $\begin{array}{c}0.603 \\
(0.022)\end{array}$ & $\begin{array}{c}0.544 \\
(0.006)\end{array}$ & $\begin{array}{c}0.588 \\
(0.009)\end{array}$ & $\begin{array}{c}0.603 \\
(0.014)\end{array}$ & $\begin{array}{c}0.592 \\
(0.012)\end{array}$ & $\begin{array}{c}0.433 \\
(0.011)\end{array}$ & $\begin{array}{c}0.651 \\
(0.051)\end{array}$ & $\begin{array}{c}0.580 \\
(0.006)\end{array}$ & $\begin{array}{c}0.553 \\
(0.008)\end{array}$ & $\begin{array}{c}0.555 \\
(0.018)\end{array}$ \\
\hline \multirow[t]{4}{*}{$\mathrm{H}(2)$} & PRE & $\begin{array}{c}0.507 \\
(0.014)\end{array}$ & $\begin{array}{c}0.297 \\
(0.007)\end{array}$ & $\begin{array}{c}0.450 \\
(0.010)\end{array}$ & $\begin{array}{c}0.363 \\
(0.002)\end{array}$ & $\begin{array}{c}0.231 \\
(0.004)\end{array}$ & $\begin{array}{c}0.386 \\
(0.010)\end{array}$ & $\begin{array}{c}0.411 \\
(0.017)\end{array}$ & $\begin{array}{c}0.280 \\
(0.001)\end{array}$ & $\begin{array}{c}0.259 \\
(0.020)\end{array}$ & $\begin{array}{c}0.413 \\
(0.022)\end{array}$ & $\begin{array}{l}-0.355 \\
(0.239)\end{array}$ \\
\hline & GFC & $\begin{array}{c}0.404 \\
(0.010)\end{array}$ & $\begin{array}{c}0.424 \\
(0.021)\end{array}$ & $\begin{array}{c}0.417 \\
(0.021)\end{array}$ & $\begin{array}{c}0.398 \\
(0.007)\end{array}$ & $\begin{array}{c}0.396 \\
(0.014)\end{array}$ & $\begin{array}{c}0.365 \\
(0.027)\end{array}$ & $\begin{array}{c}0.353 \\
(0.012)\end{array}$ & $\begin{array}{c}0.340 \\
(0.022)\end{array}$ & $\begin{array}{c}0.348 \\
(0.008)\end{array}$ & $\begin{array}{c}0.370 \\
(0.013)\end{array}$ & $\begin{array}{c}0.327 \\
(0.024)\end{array}$ \\
\hline & EDC1 & $\begin{array}{c}0.402 \\
(0.009)\end{array}$ & $\begin{array}{c}0.397 \\
(0.015)\end{array}$ & $\begin{array}{c}0.372 \\
(0.018)\end{array}$ & $\begin{array}{c}0.396 \\
(0.005)\end{array}$ & $\begin{array}{c}0.417 \\
(0.006)\end{array}$ & $\begin{array}{c}0.380 \\
(0.010)\end{array}$ & $\begin{array}{c}0.326 \\
(0.009)\end{array}$ & $\begin{array}{c}0.315 \\
(0.020)\end{array}$ & $\begin{array}{c}0.436 \\
(0.007)\end{array}$ & $\begin{array}{c}0.388 \\
(0.009)\end{array}$ & $\begin{array}{c}0.360 \\
(0.005)\end{array}$ \\
\hline & EDC2 & $\begin{array}{c}0.461 \\
(0.009)\end{array}$ & $\begin{array}{c}0.393 \\
(0.022)\end{array}$ & $\begin{array}{c}0.412 \\
(0.021)\end{array}$ & $\begin{array}{c}0.451 \\
(0.006)\end{array}$ & $\begin{array}{c}0.456 \\
(0.006)\end{array}$ & $\begin{array}{c}0.429 \\
(0.015)\end{array}$ & $\begin{array}{c}0.213 \\
(0.006)\end{array}$ & $\begin{array}{c}0.328 \\
(0.026)\end{array}$ & $\begin{array}{c}0.491 \\
(0.009)\end{array}$ & $\begin{array}{c}0.391 \\
(0.022)\end{array}$ & $\begin{array}{c}0.280 \\
(0.009)\end{array}$ \\
\hline
\end{tabular}

Note: in this table, AU stands for Austria; BEL stands for Belgium; GER stands for German; SPA stands for Spain; FIN stands for Finland; FRA stands for France; GRE stands for Greece; IRE stands for Ireland; ITA stands for Italy; NET stands for Netherlands and POR stands for Portugal. 
This is a post-peer-review, pre-copyedit version of an article published in Annals of Operations Research. The final authenticated version is available online at: https://doi.org/10.1007/s10479-018-2850-y

Table 6(b). Average Hurst Index by sub-period and maturity for 1-minute data

\begin{tabular}{lccc}
\hline Sub-periods & 3-year & 6-year & 10-year \\
\hline PRE & 0.388 & 0.361 & 0.381 \\
GFC & 0.541 & 0.569 & 0.580 \\
EDC1 & 0.644 & 0.625 & 0.595 \\
EDC2 & 0.680 & 0.644 & 0.573 \\
\hline
\end{tabular}


This is a post-peer-review, pre-copyedit version of an article published in Annals of Operations Research. The final authenticated version is available online at: https://doi.org/10.1007/s10479-018-2850-y

\section{Appendix. Robustness Test of Hurst Index estimation.}

\begin{tabular}{|c|c|c|c|c|c|c|c|c|c|c|c|c|}
\hline Maturity & Test & $\mathbf{A U}$ & BEL & GER & SPA & FIN & FRA & GRE & IRE & ITA & NET & POR \\
\hline \multirow{4}{*}{3 Years } & $\mathrm{H}(1)$ & 0.514 & 0.493 & 0.453 & 0.547 & 0.505 & 0.461 & 0.562 & 0.584 & 0.518 & 0.488 & 0.624 \\
\hline & & $(0.038)$ & $(0.032)$ & $(0.042)$ & $(0.036)$ & $(0.035)$ & $(0.032)$ & (0.029) & $(0.045)$ & $(0.029)$ & $(0.033)$ & $(0.025)$ \\
\hline & $\mathrm{H}(2)$ & 0.333 & 0.309 & 0.285 & 0.385 & 0.343 & 0.308 & 0.289 & 0.305 & 0.363 & 0.317 & 0.325 \\
\hline & & $(0.031)$ & $(0.027)$ & $(0.034)$ & $(0.031)$ & $(0.033)$ & $(0.026)$ & $(0.014)$ & $(0.023)$ & $(0.030)$ & $(0.025)$ & (0.013) \\
\hline \multirow[t]{4}{*}{6 Years } & $\mathrm{H}(1)$ & 0.510 & 0.481 & 0.432 & 0.527 & 0.528 & 0.466 & 0.555 & 0.550 & 0.488 & 0.478 & 0.604 \\
\hline & & (0.033) & $(0.028)$ & $(0.040)$ & $(0.032)$ & (0.036) & $(0.034)$ & (0.007) & $(0.033)$ & $(0.032)$ & $(0.033)$ & $(0.028)$ \\
\hline & $\mathrm{H}(2)$ & 0.325 & 0.289 & 0.276 & 0.371 & 0.354 & 0.302 & 0.286 & 0.286 & 0.342 & 0.300 & 0.317 \\
\hline & & $(0.026)$ & $(0.021)$ & $(0.032)$ & $(0.026)$ & $(0.034)$ & $(0.025)$ & (0.003) & $(0.018)$ & (0.029) & $(0.026)$ & (0.015) \\
\hline \multirow[t]{4}{*}{10 Years } & $\mathrm{H}(1)$ & 0.477 & 0.457 & 0.412 & 0.503 & 0.511 & 0.442 & 0.518 & 0.427 & 0.479 & 0.447 & 0.551 \\
\hline & & $(0.036)$ & $(0.025)$ & $(0.037)$ & $(0.027)$ & (0.036) & $(0.031)$ & (0.018) & $(0.031)$ & $(0.034)$ & $(0.031)$ & $(0.027)$ \\
\hline & $\mathrm{H}(2)$ & 0.315 & 0.279 & 0.260 & 0.368 & 0.343 & 0.285 & 0.267 & 0.216 & 0.348 & 0.281 & 0.285 \\
\hline & & (0.031) & $(0.018)$ & $(0.031)$ & $(0.023)$ & (0.033) & $(0.022)$ & (0.008) & $(0.015)$ & (0.032) & $(0.025)$ & $(0.014)$ \\
\hline
\end{tabular}


This is a post-peer-review, pre-copyedit version of an article published in Annals of Operations Research. The final authenticated version is available online at: https://doi.org/10.1007/s10479-018-2850-y

\begin{tabular}{|c|c|c|c|c|c|c|c|c|c|c|c|c|}
\hline Maturity & Test & $\mathrm{AU}$ & BEL & GER & SPA & FIN & FRA & GRE & IRE & ITA & NET & POR \\
\hline \multirow[t]{4}{*}{3 Years } & $\mathrm{H}(1)$ & 0.348 & 0.346 & 0.292 & 0.356 & 0.347 & 0.306 & 0.462 & 0.402 & 0.350 & 0.328 & 0.477 \\
\hline & & $(0.043)$ & $(0.042)$ & $(0.046)$ & $(0.052)$ & (0.038) & $(0.032)$ & $(0.020)$ & $(0.046)$ & $(0.056)$ & $(0.045)$ & $(0.052)$ \\
\hline & $\mathrm{H}(2)$ & 0.205 & 0.194 & 0.168 & 0.229 & 0.204 & 0.181 & 0.238 & 0.207 & 0.222 & 0.193 & 0.247 \\
\hline & & $(0.032)$ & $(0.029)$ & $(0.038)$ & $(0.041)$ & $(0.032)$ & $(0.025)$ & $(0.010)$ & $(0.024)$ & $(0.043)$ & $(0.036)$ & $(0.028)$ \\
\hline \multirow[t]{4}{*}{6 Years } & $\mathrm{H}(1)$ & 0.378 & 0.342 & 0.290 & 0.346 & 0.385 & 0.318 & 0.493 & 0.385 & 0.324 & 0.317 & 0.454 \\
\hline & & $(0.028)$ & $(0.043)$ & $(0.032)$ & $(0.055)$ & $(0.033)$ & $(0.031)$ & $(0.025)$ & $(0.054)$ & $(0.046)$ & $(0.049)$ & $(0.056)$ \\
\hline & $\mathrm{H}(2)$ & 0.225 & 0.193 & 0.170 & 0.227 & 0.225 & 0.193 & 0.257 & 0.196 & 0.216 & 0.179 & 0.235 \\
\hline & & $(0.019)$ & $(0.029)$ & $(0.022)$ & $(0.046)$ & $(0.026)$ & $(0.023)$ & $(0.013)$ & $(0.029)$ & $(0.036)$ & $(0.038)$ & $(0.030)$ \\
\hline \multirow[t]{4}{*}{10 Years } & $\mathrm{H}(1)$ & 0.325 & 0.323 & 0.280 & 0.343 & 0.352 & 0.304 & 0.444 & 0.294 & 0.296 & 0.306 & 0.423 \\
\hline & & $(0.038)$ & $(0.041)$ & $(0.035)$ & $(0.053)$ & $(0.040)$ & $(0.035)$ & $(0.024)$ & $(0.018)$ & $(0.049)$ & $(0.038)$ & $(0.058)$ \\
\hline & $\mathrm{H}(2)$ & 0.190 & 0.188 & 0.168 & 0.243 & 0.205 & 0.194 & 0.232 & 0.147 & 0.195 & 0.177 & 0.217 \\
\hline & & $(0.031)$ & $(0.028)$ & $(0.027)$ & $(0.044)$ & $(0.032)$ & $(0.026)$ & $(0.012)$ & $(0.010)$ & $(0.038)$ & $(0.029)$ & $(0.030)$ \\
\hline
\end{tabular}

Note: in this table, AU stands for Austria; BEL stands for Belgium; GER stands for German; SPA stands for Spain; FIN stands for Finland; FRA stands for France; GRE stands for Greece; IRE stands for Ireland; ITA stands for Italy; NET stands for Netherlands and POR stands for Portugal. 